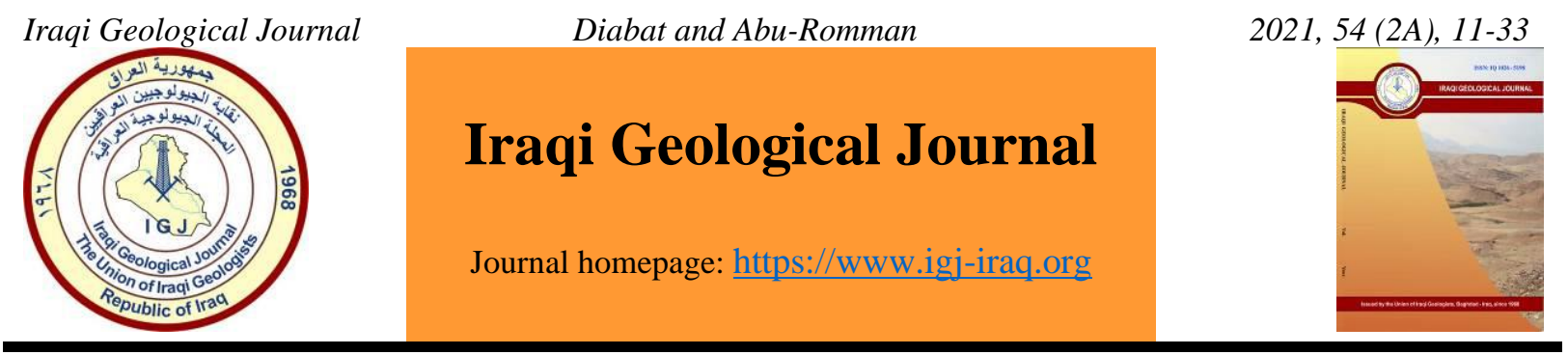

\title{
Rock Slope Stability Assessment Using Kinematic Analysis of the Limestone Quarries in Al Huson-Shatana Area, Jordan
}

\author{
Abdullah Diabat ${ }^{1}$ * and Waleed Abu-Romman ${ }^{1}$ \\ ${ }^{1}$ Department of Applied Earth and Environmental Sciences, Institute of Earth and Environmental Sciences, Al al-Bayt \\ University \\ * Correspondence: adiabat@aabu.edu.jo
}

Received: 31 October 2020; Accepted: 22 April 2021; Published: 31 July 2021

\begin{abstract}
The current study presents the first results of a kinematic analysis to investigate the type of failures in six abandoned limestone quarries in the Al-Huson-Shatana area, North Jordan. A serious problem appears in abandoned quarries. When the work in the quarry finish and the companies withdraw their equipment and workers, they leave behind unstable rock masses due to the repeated explosives. This may cause hazards in properties and civilians especially when they are close enough to residential areas. Both stereographic projection and kinematic analysis were used as tools in this study, to determine the mode and orientation of the failures. Results show that toppling, planar and wedge failures are likely to occur in all stations mainly along structural discontinuities, faults and joints. This indicates the role of structures in the rock landslides, particularly those related to planar, wedge and toppling failures. In addition, rock falls were observed in most stations that have steep slope cutting.
\end{abstract}

Keywords: Slope stability; Kinematic analysis; Abandoned quarries; Jordan

\section{Introduction}

Rock slope failure hazard is a global phenomenon. The study of these failures can help to avoid the possible risks to the environment and communities. The limestone deposits are spread from Irbid in the north to Ma'an in the southern part of Jordan; and also, of the upper Cretaceous age in the first stage and of the Eocene age in the second (Abed, 2000). The importance of the quarrying activity centered on producing traditional hard flooring materials, such as granite, sandstone, slate, limestone, marble and even just clay to produce ceramic tiles. The most important use of the limestone in the study area is as a building stone. Currently, pure limestone is mined, for producing white cement, magnesia, and calcium carbonate. Initially, the quarries were often built out of the borders of the urban area to avoid environmental problems and rock slides that may occur. But due to population growth, the housing projects increase and get closer to the quarries. Both active and abandoned quarries in the study area become surrounded by homes, main roads, and even passers-by. These quarries become a source of danger as land sliding can take place within these areas. Rock stability assessment becomes an indispensable technique, help us to avoid potential risks. However, one of the negative impacts of quarrying is the destruction of the natural landscape, which may create an open space in the ground and

DOI: $10.46717 /$ igj.54.2A.2Ms-2021-07-23 
may generate heaps of rock wastes that cannot be easily disposed of, and some of the quarries do not have a proper fence around their surroundings, and this is very dangerous for people who pass through the area and may fall into the quarry pit. Several quarries that have been abandoned and they act as a dumping site. Blasting is a standard method for excavating rock aggregates in quarry operation but the uncontrolled blasting technique resulted in unstable rock slopes (Samarawickrama et al., 2006). Geo-environmental problems identified in abandoned quarry sites include slope stability problems such as sliding, toppling and rock mass quality (Koca and Kincal, 2004). The excessive over-break, unstable and loose overhanging blocks are attributable to improper blasting design (Abad et al., 2011). This can present a threat to the environment and a danger to humans because it is disadvantageous to the situation of stability. Instability of slopes and failures take place due to many factors such as adverse slope geometries, geological discontinuities, weak or weathered slope (Basahel and Marti, 2017). Slope stability problems have begun targeting research concerns. Several slope stability assessment techniques and methods have been proposed. It is possible to group these methods into four categories, kinematic analysis, limit equilibrium, numerical modeling, and empirical methods (Basahel and Marti, 2017). The current study aims to determine and measure the discontinuities (faults, joints, veins, bedding planes) and their orientation that could affect the slope stability of the quarries and to distinguish their types. This study carried out a kinematic analysis to investigate and to shed light on type of failures in six abandoned quarries in Al- Huson area (Fig. 1). The study area is located in the northern part of Jordan to the south of Irbid city. It is located between coordinates $35^{\circ} 49^{\prime} 33.3768^{\prime \prime}-35^{\circ} 53^{\prime} 56.3460^{\prime \prime} \mathrm{E}$ and $32^{\circ} 25^{\prime} 31.4652^{\prime \prime}-32^{\circ} 28^{\prime} 28.5636 " \mathrm{~N}$ covering of about $32 \mathrm{Km}^{2}$. However, the study area is easily accessible via Huson road then Huson-Shatana quarries road (Fig. 1). The study area lies in the northern highlands of Jordan according Bender (1974). In general, it is hilly with elevations between 690 and $1007 \mathrm{~m}$ above sea level. It is cut by many wadis and their minor branches (Fig. 2).
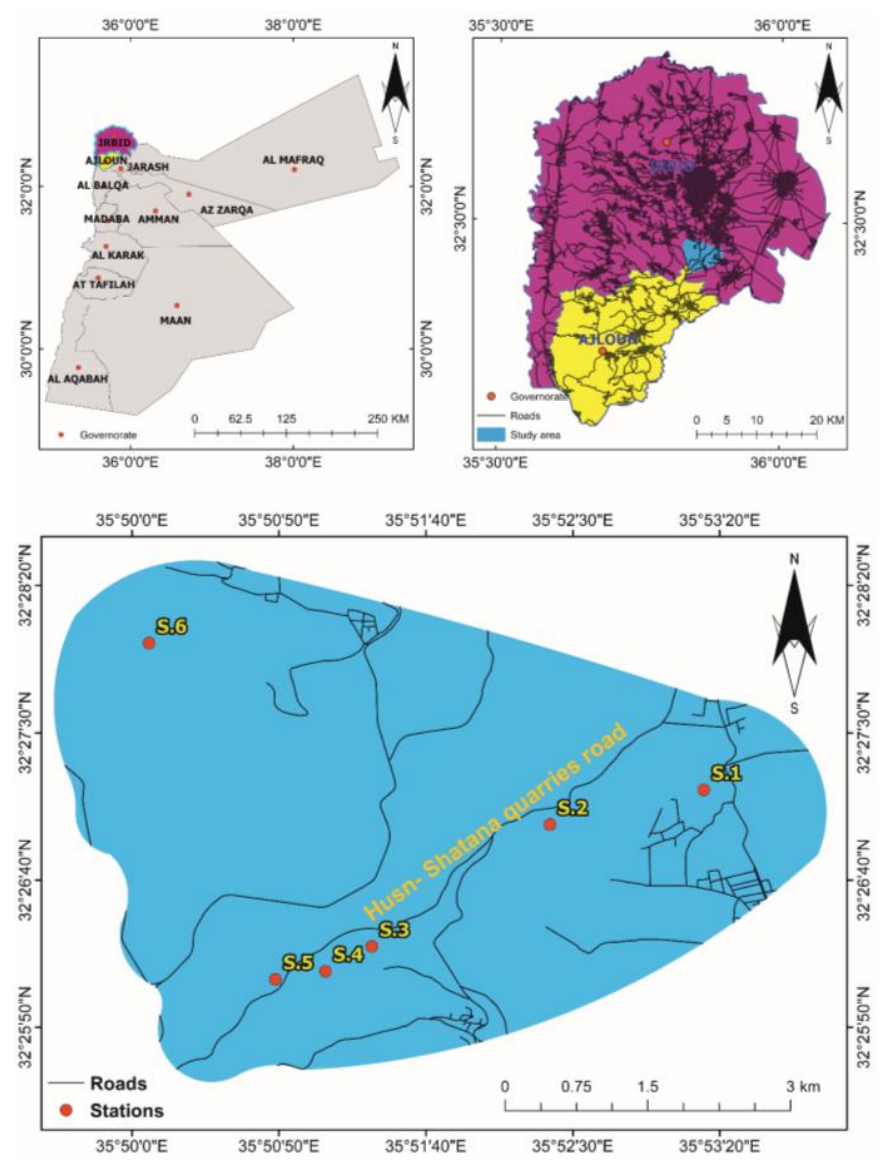

Fig. 1. Location maps of the study area and the location of the quarries S1, S2 and S6 


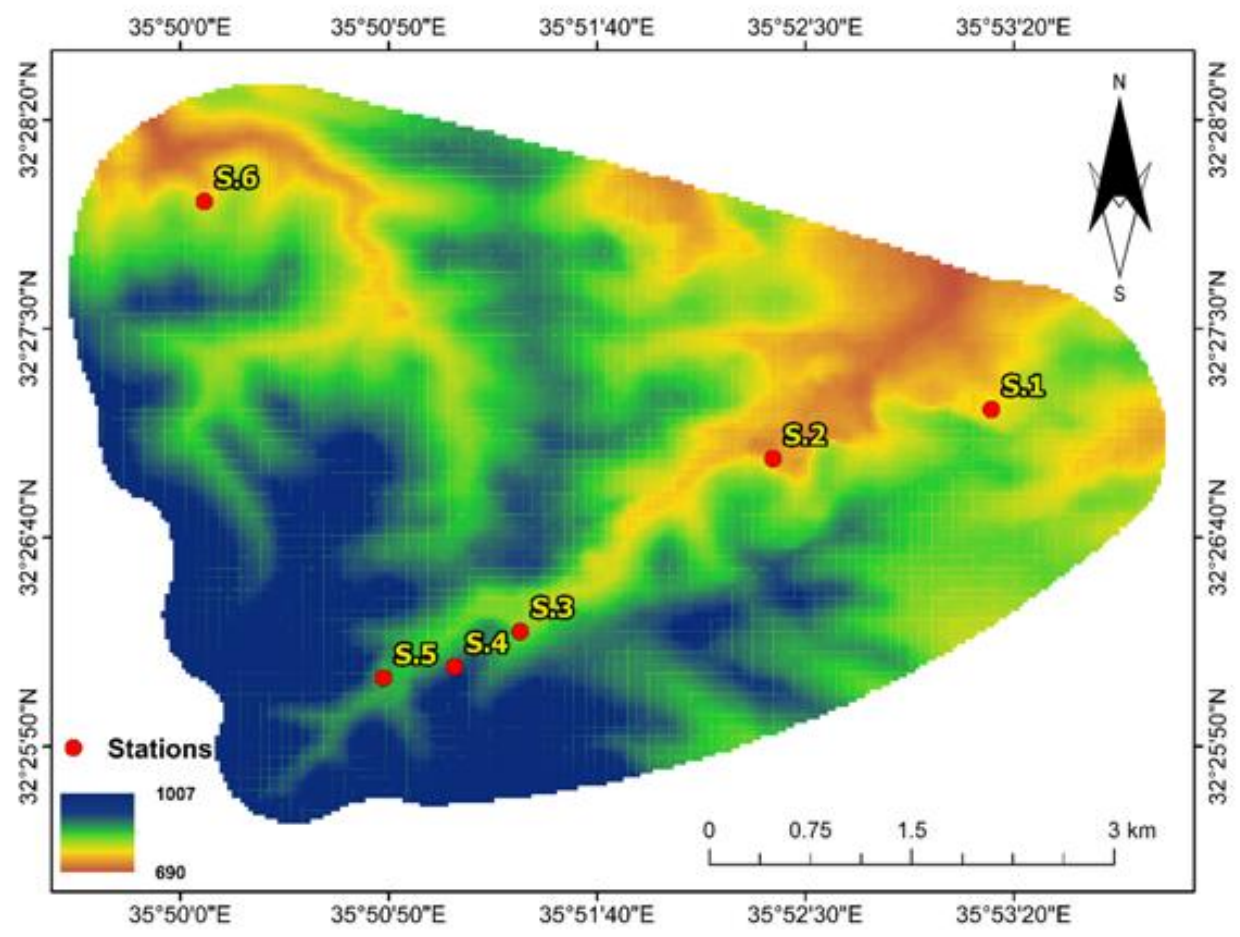

Fig. 2. Digital elevation map of the study area

\section{Materials and Methods}

\subsection{Field work}

The field work focused basically on measuring detailed and accurate attitudes of the structural data (discontinuities e.g., faults, joints, veins, bedding planes). Also, taking photos and detailed field observations formed a vital part through this part; taking photo of the quarry walls intensively affected by discontinuities that probable to enhance failure.

\subsection{Office work}

Office work can be summarized as follows:

- Stereographic projection techniques, which are suitable for slope stability analysis, particularly for identifying kinematically possible modes of failure.

- The stereonet of the discontinuities set at each quarry was drawn using Stereonet software to determine the potential modes of failure i.e., Planar failure, wedge failure and toppling failure.

- Stereographic representation of the structural conditions which can determine slope stability is drawn as stereo plot involving the great circle that represents the slope face. The poles of the discontinuities, the contour lines of pole concentrations and the great circle normal to the centers of the main pole concentration.

- The friction angle of the discontinuities in a rock mass, is supposed to be 35 degrees based on Barton (1973) and Jaeger and Cook (1976) as shown in Table 1. The friction angles listed in this table should be used as a guideline only because actual values will vary widely with site conditions.

- Arc map GIS 10.2 and Arc Scene 10.2 were used to redraw and produce a detailed geological map of the study area and to analyze and produce digital elevation map. 
Table 1. Typical ranges of friction angles for a variety of rock types (after, Barton 1973; Jaeger and Cook, 1976)

\begin{tabular}{lcc}
\hline Typical rock types & Friction angle range & Rock class \\
\hline $\begin{array}{l}\text { Schists (high mica content), } \\
\text { shale, marl }\end{array}$ & $20-27 \circ$ & Low friction \\
$\begin{array}{l}\text { Sandstone, siltstone, chalk, } \\
\text { gneiss, slate }\end{array}$ & $27-34 \circ$ & Medium friction \\
$\begin{array}{l}\text { Basalt, granite, limestone, } \\
\text { conglomerate }\end{array}$ & $34-40 \circ$ & High friction \\
\hline
\end{tabular}

\section{Geological Setting}

Throughout most of Jordan, Wadi As Sir Formation (Turonian) (Fig. 3) represents the topmost part of the Ajlun Group and is disconformably overlain by the white chalk of the basal Belqa Group (Powell,1989). The Wadi As Sir Formation is characterized by its white to very light gray limestone, microcrystalline and thinly bedded with very thin marl parting, fractured, medium-hard concretionary, become chalky at the top and base. They can easily be defined from the overlying marl of the base of Umm Ghudran Formation (Masri,1963).This formation consists of three distinctive parts, the lower part is formed of dolomite, dolomitic limestone and/or recrystallized limestone, the middle part consists of relatively soft marly limestone and limestone, and the upper part consists almost totally of thick bedded to massive limestone (Abdelhamid,1995).This formation is widely spreading and outcropping and represent the area of limestone reserve for quarrying in the study area (Fig. 3).

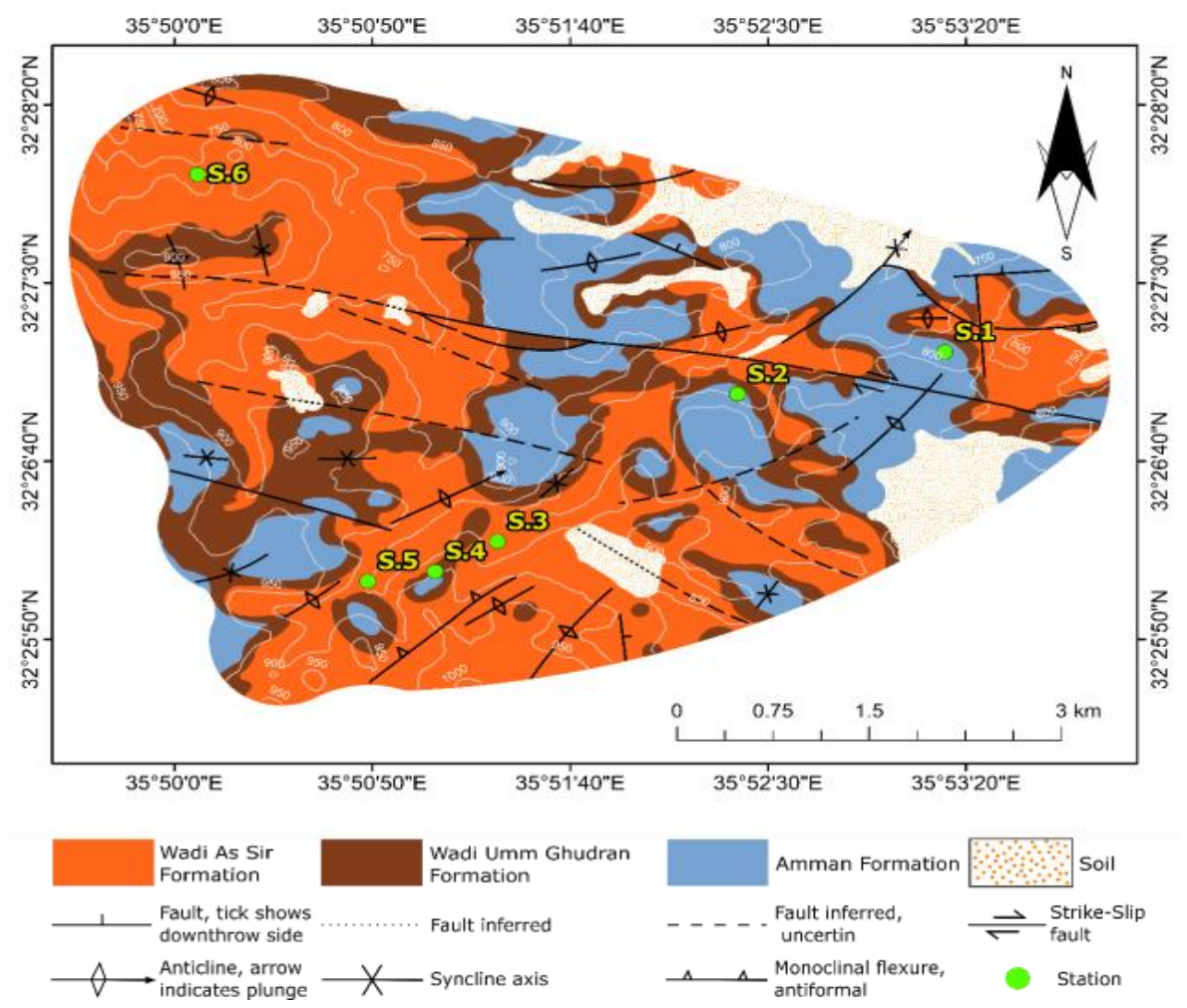

Fig. 3. Geological map of the study area (Modified from Abdelhamid, 1995) 
The study area lies within the Highlands east Jordan Valley Fault (JVF). It lies within the area that is affected by the Dead Sea Transform Fault (DSTF). This fault constitutes plate boundary between African and Arabian plates (Klinger, et al., 2000) (Fig. 4a). The DSTF is the most impressive tectonic feature in the region (Ben-Avraham, et al., 2005). It is an active left-lateral fault zone (Masson, et al., 2015) that spans for more than $1100 \mathrm{~km}$ from the Red Sea to the Taurus mountains in Turkey (Diner, 2019).

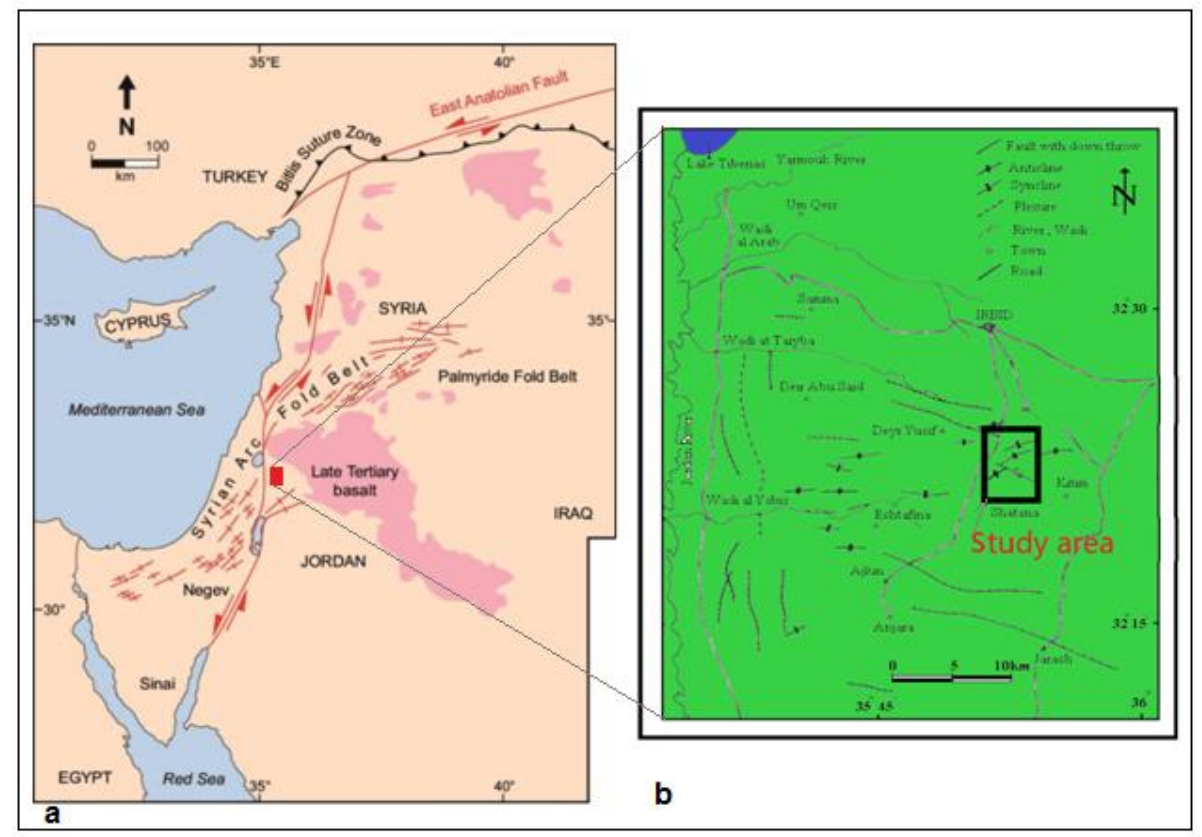

Fig. 4. A. Regional tectonic map shows the Dead Sea Transform and the Syrian Arc Fold Belt extending from northern Sinai, through the Negev and Jordan, and into central Syria (After Abed, 2013) b. Structural setting of the study area and major structures in northern Jordan (modified after Al Khatib et al., 2010)

The Syrian Arc Fold Belt (SAB) is one of the most important geological systems in the region. It controls the topography of the area to form heights and depressions and it spans in S-shape from northern Sinai to Lebanon and southern Syria (Fig.4a) (Al-Tawalbeh, et al., 2017).

\section{Results and Discussion}

Six stations were investigated in this study, five of which are located on the Huson-Shatana road, while the sixth station located to the west, close to the Habaka village (Fig. 3).

\subsection{Station 1}

This station is located along Kitim- Huson road in abandoned quarry. Its coordinates are ( $35^{\circ} 53^{\prime} 14^{\prime \prime}$ $\mathrm{E}$ and $32^{\circ} 27^{\prime} 10^{\prime \prime} \mathrm{N}$ ) (Fig.3). About 211 of discontinuity planes (joints and faults) were measured in this station. The measurements were analyzed using rose diagram (Fig.5a) and Stereonet plot program to construct poles concentration and great circles normal to poles of maximum concentration (Fig.5b). The rose diagram of this station shows a major trend-oriented WNW- ESE, and minor trends oriented: NW-SE, WSW- ENE and N-S (Fig. 5a). The stability along four slope faces of the quarry were kinematically analyzed (Fig. 5A-D).

Results show that six sets of discontinuities probably cause unstable slopes, with respect to a distinct slope face of the 4 faces (S1, S2, S3, and S4) along the quarry (Fig. 5b). These discontinuities are J1, J2, J3, J4, J5 and J6 with attitudes (dip direction/dip angle) of 190/55, 020/60, 090/80, 250/70, $315 / 80$ and $060 / 75$, respectively. 
The slope face (S1) dipping toward NNE is parallel to the main trend of the discontinuities (Fig. 5 A), shows two wedges sliding; the first is toward NNE along the intersection line of J5 \& J6 and the second is toward NW along $\mathrm{J} 2 \& \mathrm{~J} 4$, in addition to plane sliding along $\mathrm{J} 2$ toward NNE. The slope face (S2) dipping towards $\mathrm{W}$ (Fig.5B) shows toppling along $\mathrm{J} 3$ towards $\mathrm{W}$, planar sliding along $\mathrm{J} 4$ toward WSW, in addition to two wedges sliding; the first is toward SW along the intersection line of J1\&J5, and the second toward NW along the intersection line of J2\& J4.The slope face (S3) is dipping toward E (Fig. $5 \mathrm{C}$ ), it indicates toppling along $\mathrm{J} 4$ toward ENE, planar sliding toward $\mathrm{E}$ along J3, and two wedges sliding along J1\&J6 toward SE and along J3\&J5 toward NNE. The slope face (S4) dipping toward S (Fig. $5 \mathrm{D}$ ) indicates plane sliding along $\mathrm{J} 1$ towards SSW, toppling along $\mathrm{J} 2$ toward SW and two wedges sliding along the intersection line of J1 \& J5 toward WSW and along J1\&J6 toward SE. In addition, rock falls along the quarry walls were also observed (Figs. 6- 10).

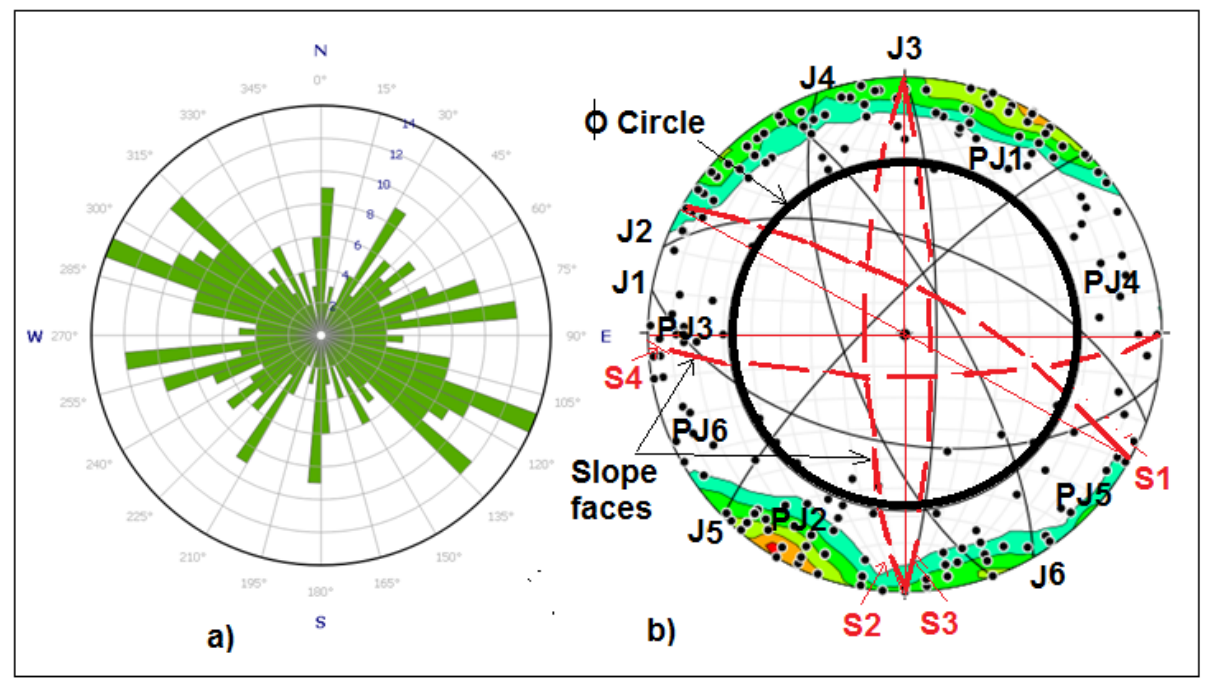

Fig. 5. Stability estimate of the rock mass in station 1; (a) Rose diagram represents strike orientation of 211discontinuities, (b) Stereonet shows poles of the discontinuities, contour plot of main concentrations of poles, and great circles normal to poles of maximum concentration: J1, J2, J3, J4, J5 and J6 in addition to four slope faces (red) and friction circle

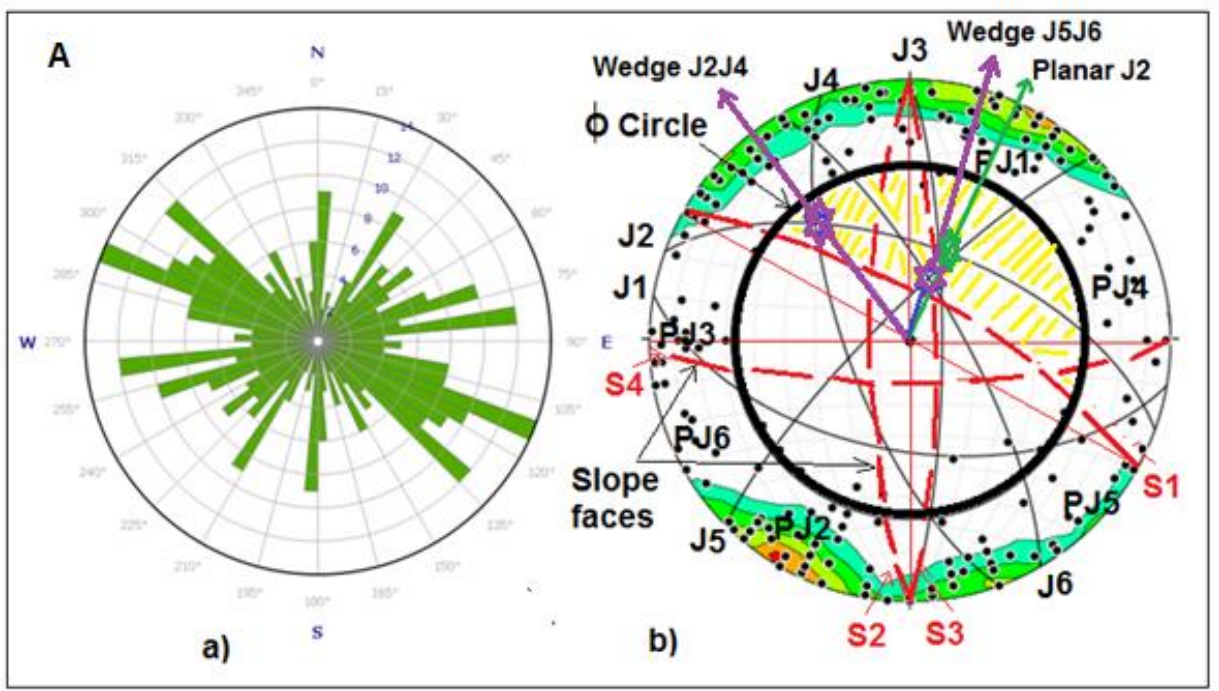

Fig. 5A. Stability estimate of the rock mass along slope face $S 1$ in station-1 


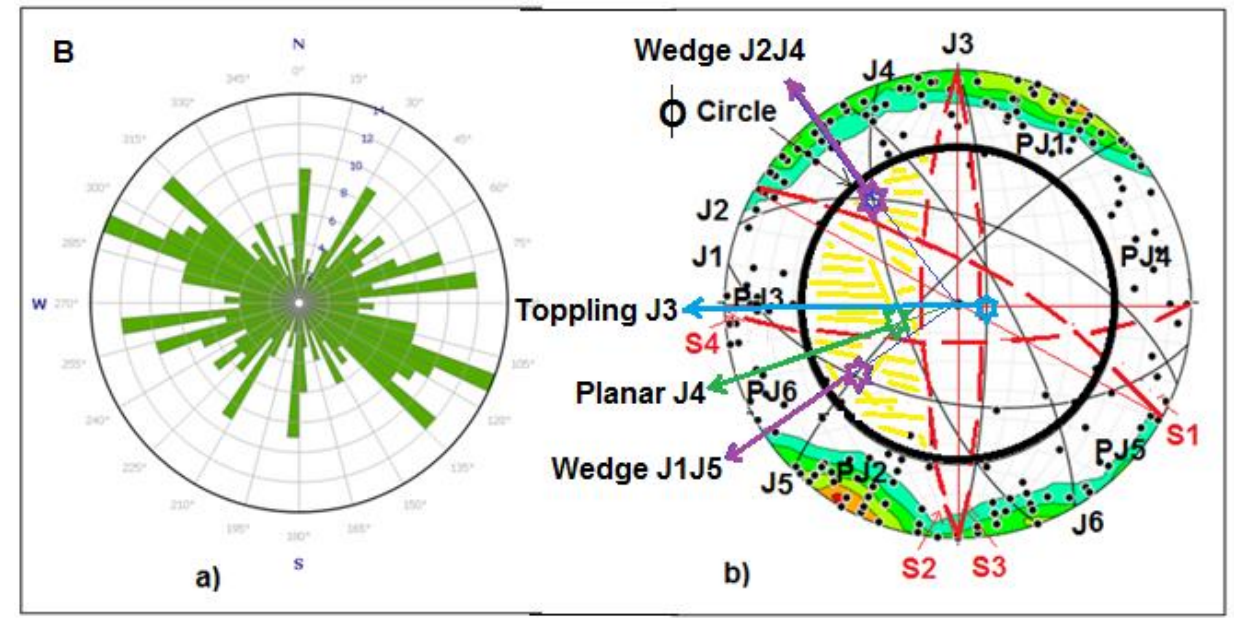

Fig. 5 B. Stability estimate of the rock mass in along slope face S2 of station-1

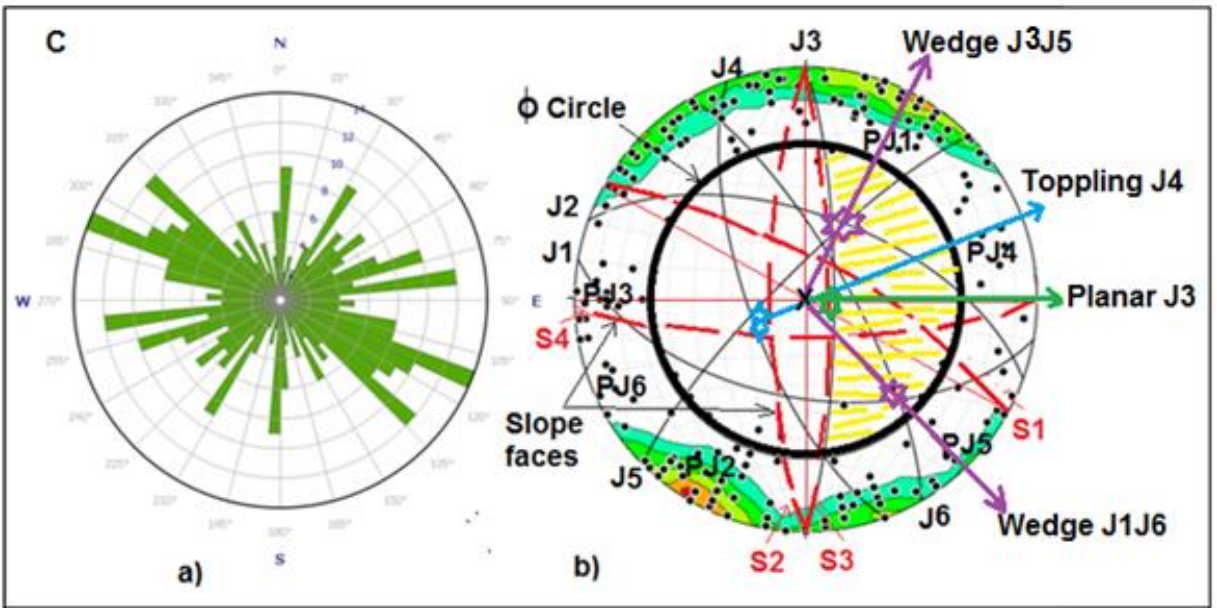

Fig. 5 C. Stability estimate of the rock mass along slope face S3 of station-1

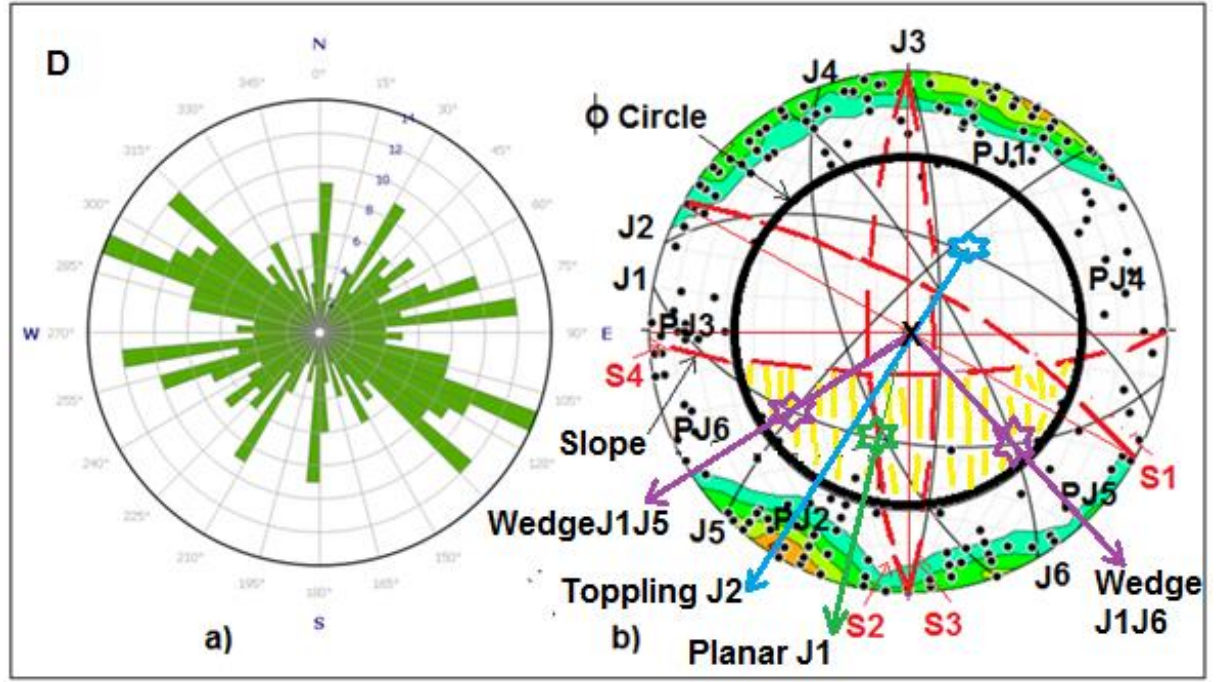

Fig. 5D. Stability estimate of the rock mass along slope face S4 of station-1 

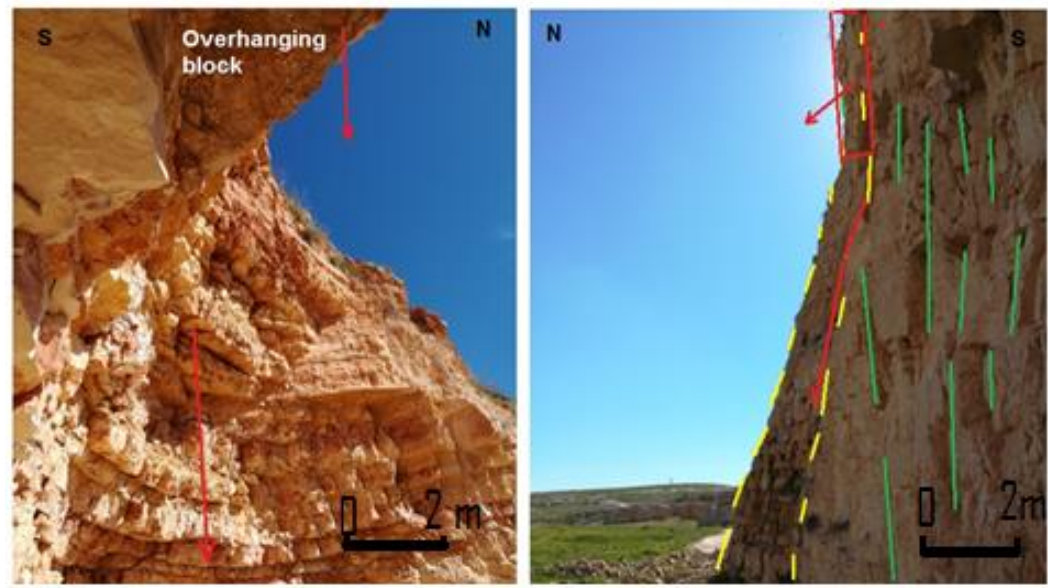

Fig. 6. Overhanging blocks probable to fall down (left), and probability of toppling (right) in highly fractured slope faces

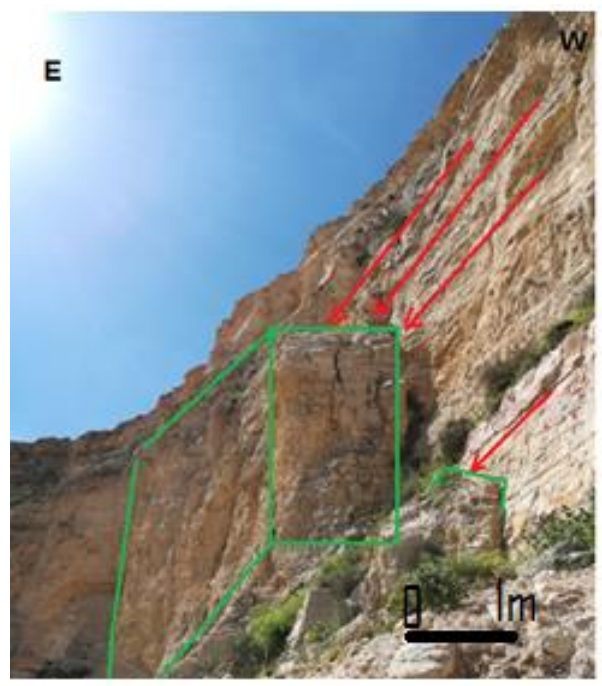

Fig.7. Planar sliding of rock masses along discontinuity plane (fault)

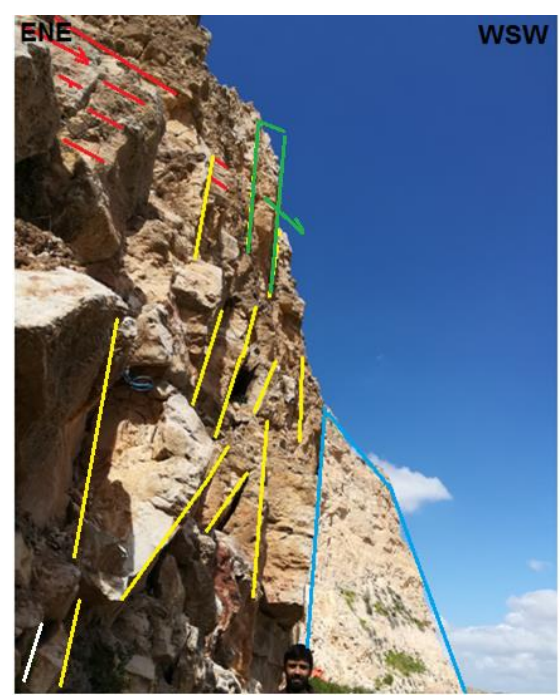

Fig. 8. Toppling (green), planar sliding (red \& blue) and rock falls 

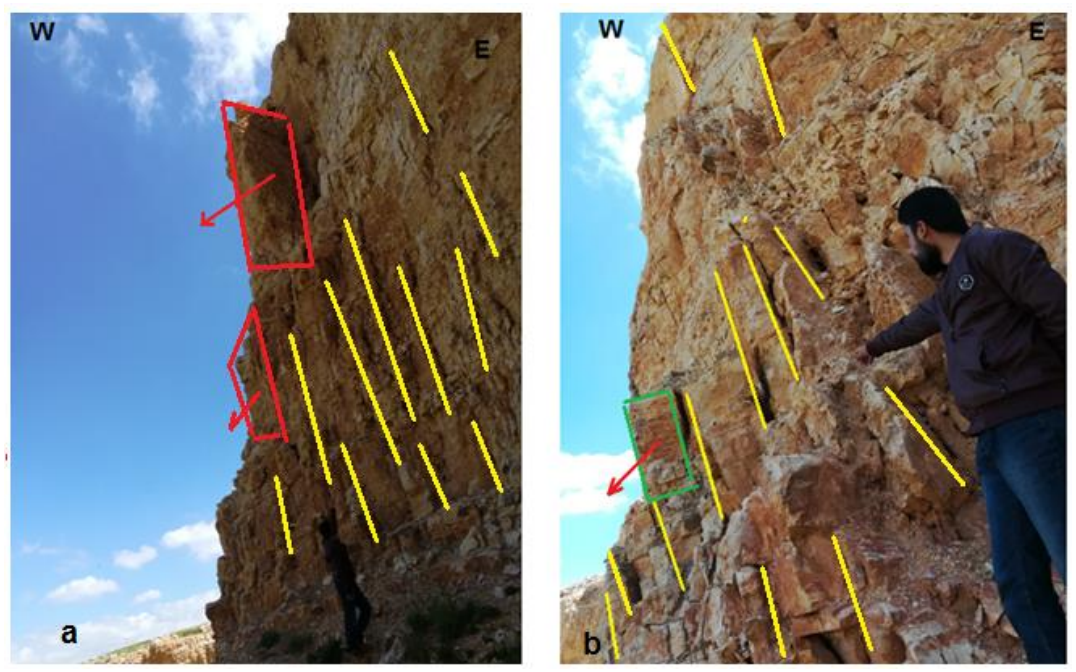

Fig. 9. Probability of toppling (red arrows), tension fractures (yellow)

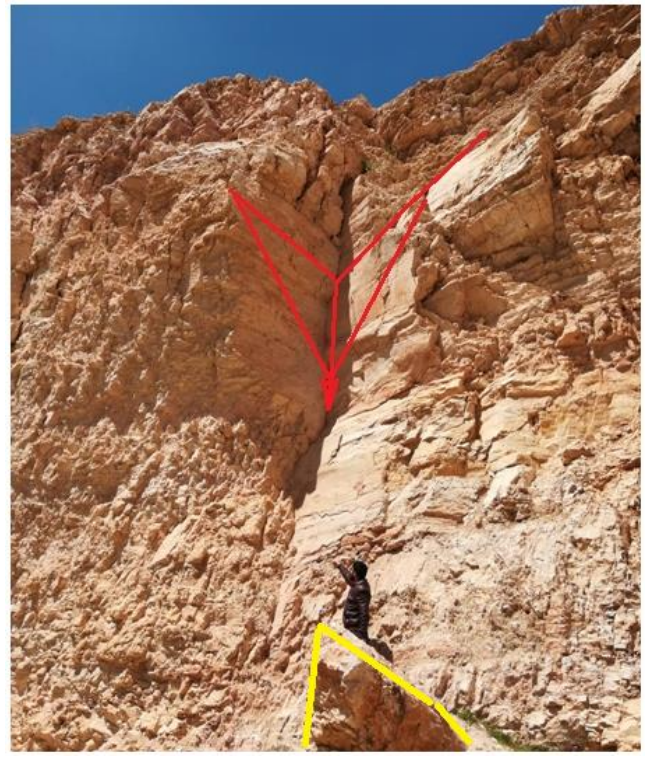

Fig. 10. Wedge sliding along the line of intersection planes in the direction of red arrow, the angular block in yellow is part of the moved block

\subsection{Station 2}

This station is an abandoned quarry located at the main Huson- Shatana quarries road, it locates at $\left(35^{\circ} 52^{\prime} 22^{\prime \prime} \mathrm{E}\right.$ and $32^{\circ} 26^{\prime} 58^{\prime \prime} \mathrm{N}$ ) (Fig. 3). Strike, dip and dip direction of 422 discontinuity planes from all side of the quarry were measured at this station and represented in rose, stereonet, pole plot diagrams (Fig. $11 \mathrm{a} \&$ b). Rose diagram shows ENE- WSW as a major trend, while NW-SE, N-S, NE-SW and others are minor trends (Fig. 11a). Results show that five sets of discontinuities are probably unstable with respect to a distinct slope face along the quarry (Fig. 11b). These discontinuities are J1, J2, J3, J4 and J5, with attitudes (dip direction/dip angle) of 170/80, 210/85, 030/85, 095/80 and 280/85, respectively. 


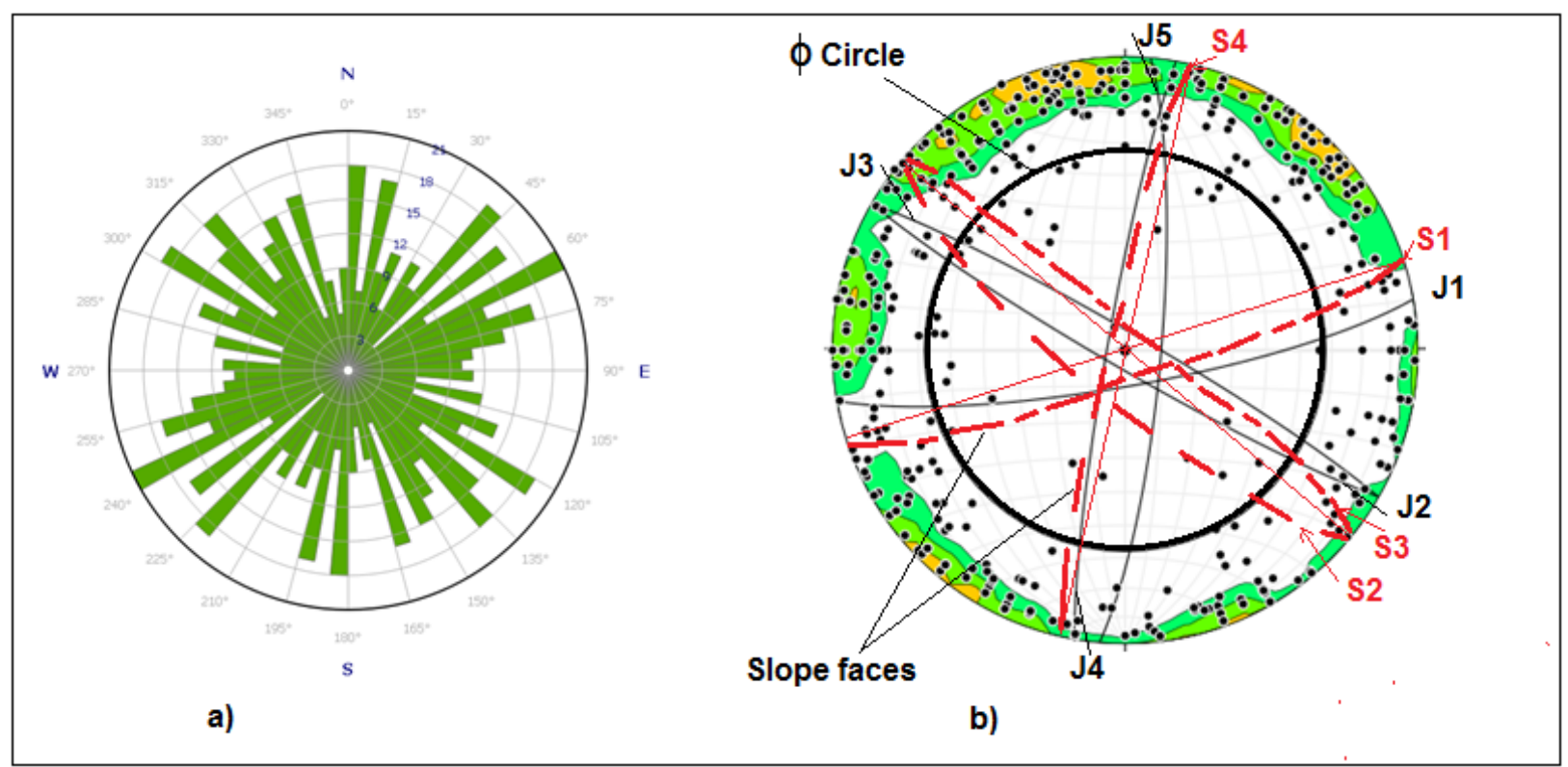

Fig.11. Stability estimate of the rock mass in station-2; (a) Strike orientation of 422 discontinuity measurements, (b) Poles of the discontinuities, contour plot of main concentrations of poles, and great circles of discontinuities normal to poles $\mathrm{J} 1, \mathrm{~J} 2, \mathrm{~J} 3, \mathrm{~J} 4$, and $\mathrm{J} 5$, 4 slope faces (red) and friction circle

The slope face (S1) dipping toward SSE that parallel to the main trend of the discontinuities (Fig. 11A) shows plane sliding along J1 toward SSE and wedge sliding along the intersection line of J2J5 toward SSE. The slope face (S2) dipping toward SSW (Fig. 11 B) shows toppling along J3 and wedge sliding along the intersection line of J1J4toward SSW. The slope face (S3) dipping toward NE (Fig. 11 C) indicates toppling along $\mathrm{J} 2$ and plane sliding along $\mathrm{J} 3$ toward NNE. The slope face (S4) dipping toward WNW (Fig. $11 \mathrm{D}$ ) indicates plane sliding along $\mathrm{J} 4$ toward W, and toppling along $\mathrm{J} 5$ toward W. In addition, rock falls along all of the quarry walls were also observed (Figs. 12- 16).

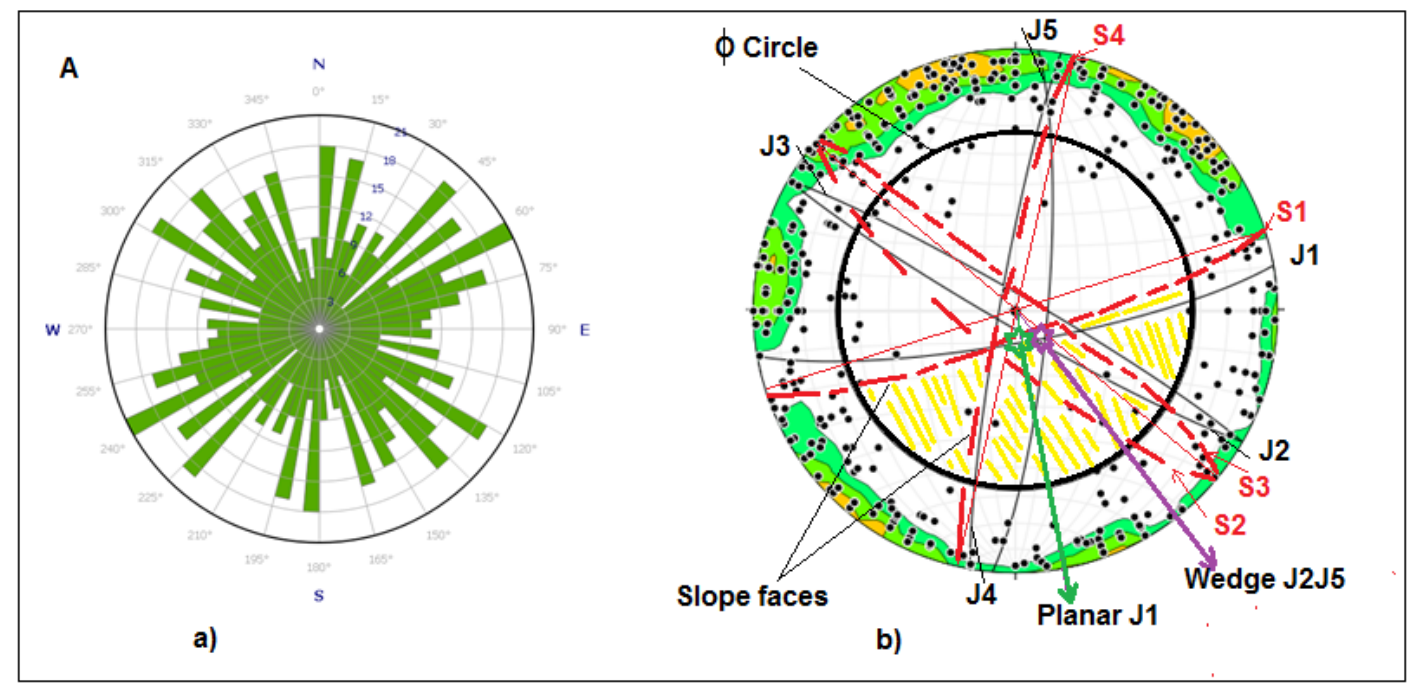

Fig.11 A. Stability estimate of the rock mass along slope face $\mathrm{S} 1$ of station- 2 


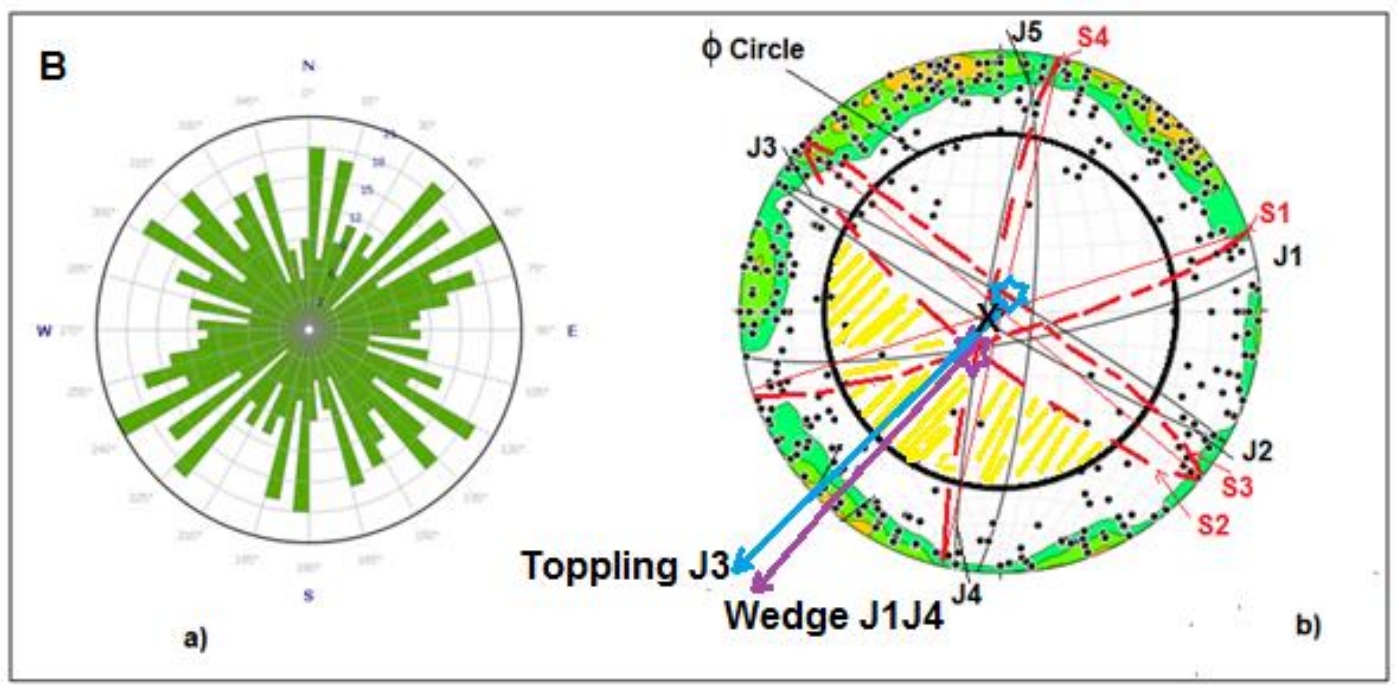

Fig.11B. Stability estimate of the rock mass along slope face $S 2$ of station- 2

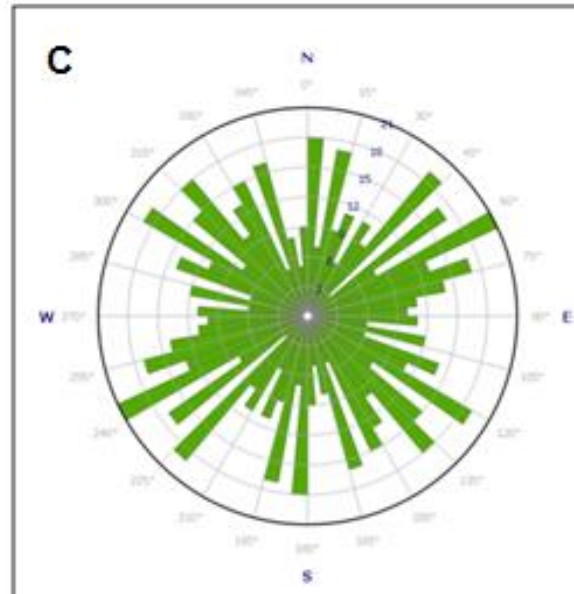

a)

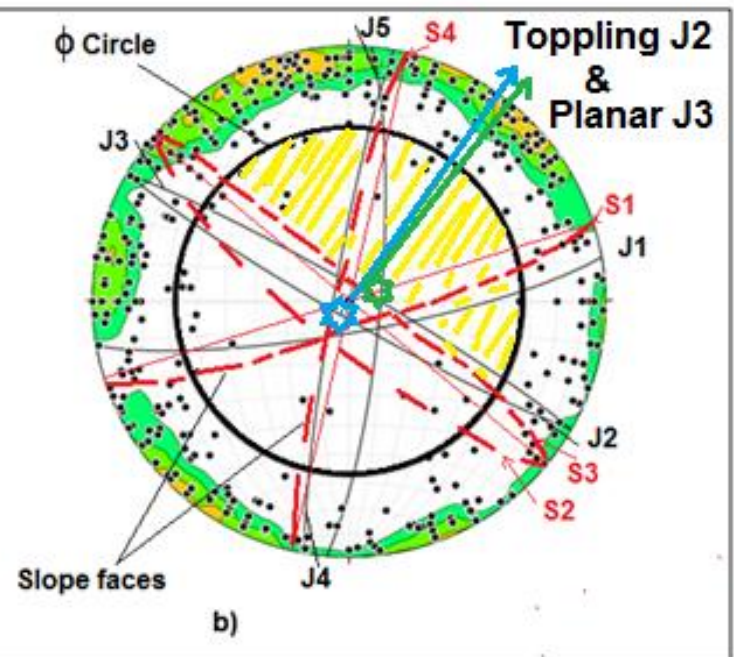

Fig.11 C. Stability estimate of the rock mass along slope face S3 of station- 2

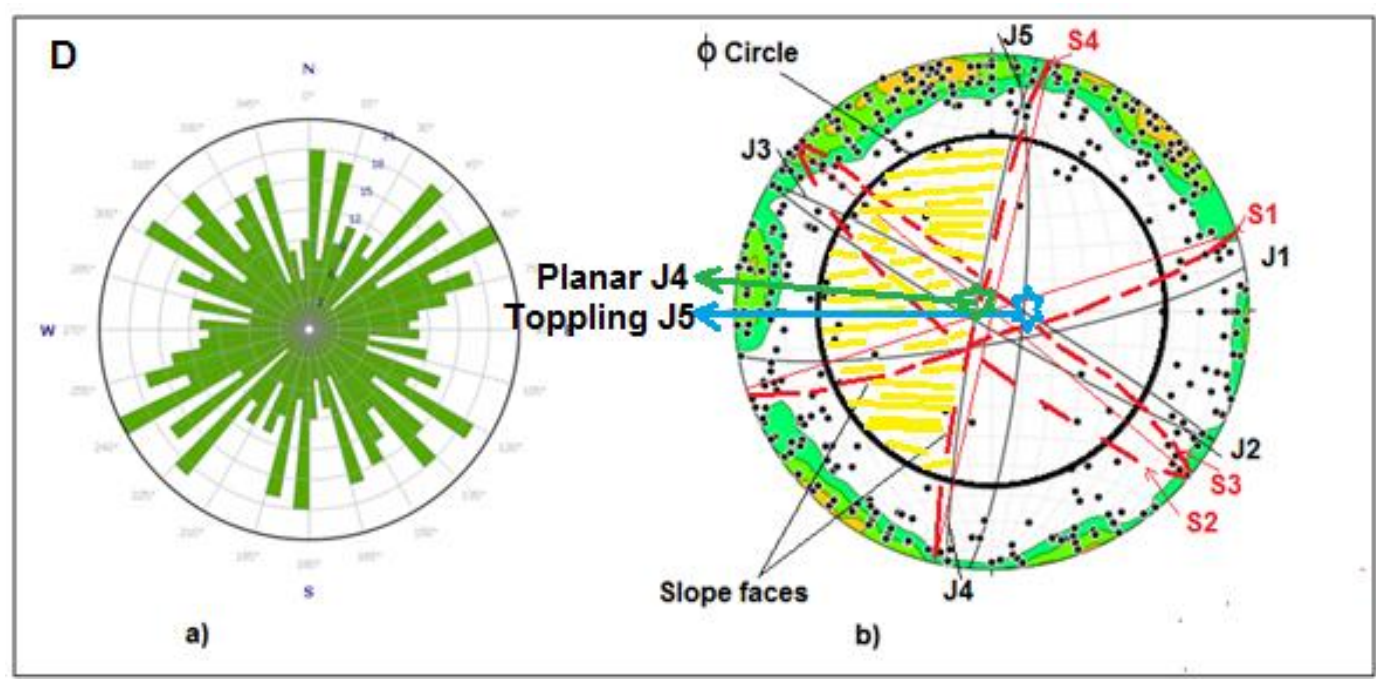

Fig.11 D. Stability estimate of the rock mass along slope face S4 of station- 2 

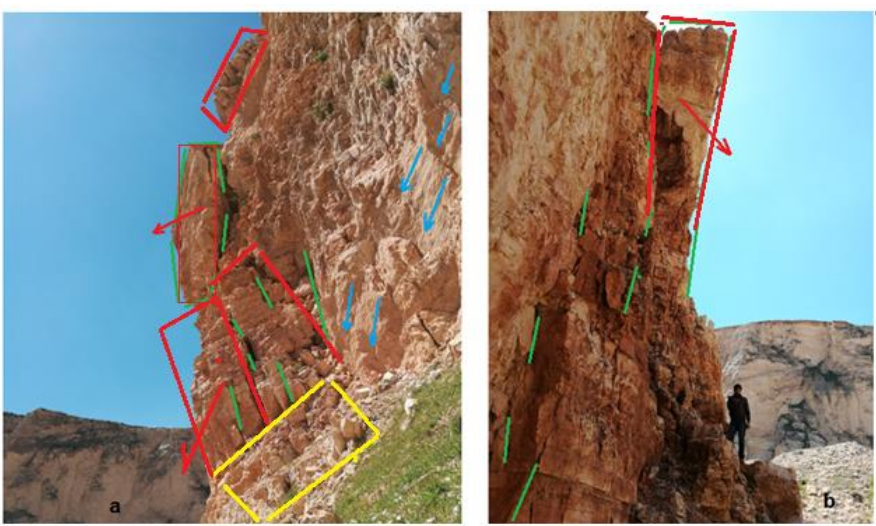

Fig.12. a. Probability of toppling and rock falls (red), plane sliding (blue), b) toppling (red), vertical fractures and tension cracks (green)

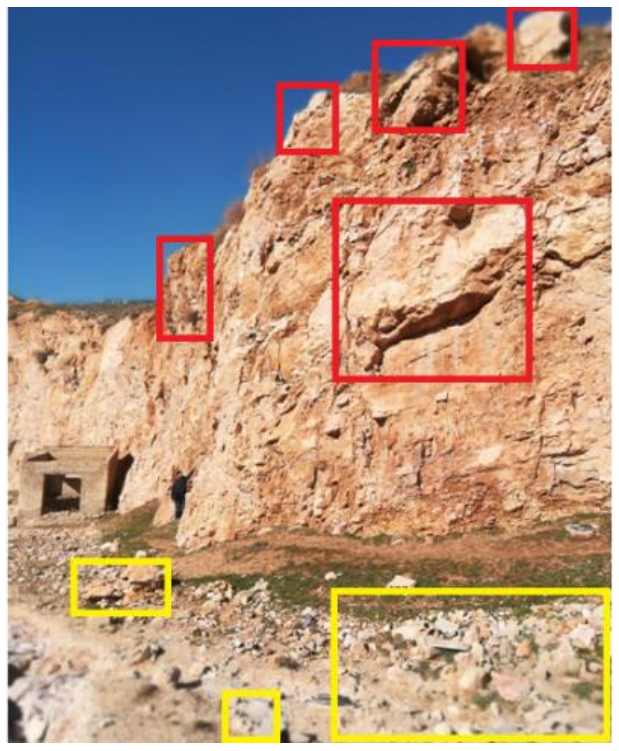

Fig.13. Protruding rocks (red) and rock falls (yellow)
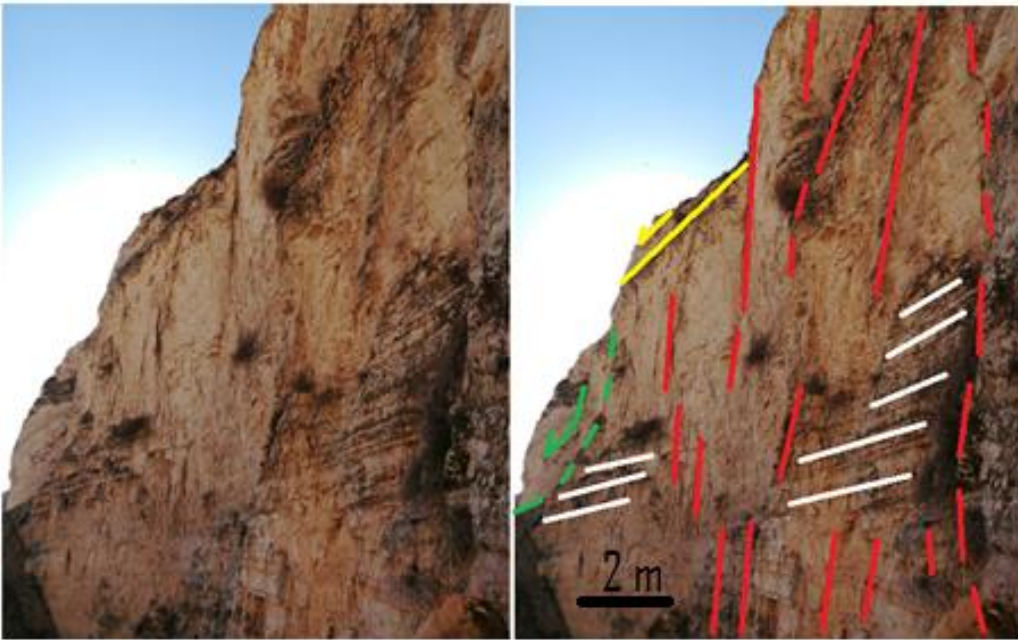

Fig.14. Highly fractured rocks with probability of planar sliding (yellow) and circular failure (green), in addition to rock falls; white lines (bedding) and red lines vertical fractures. 

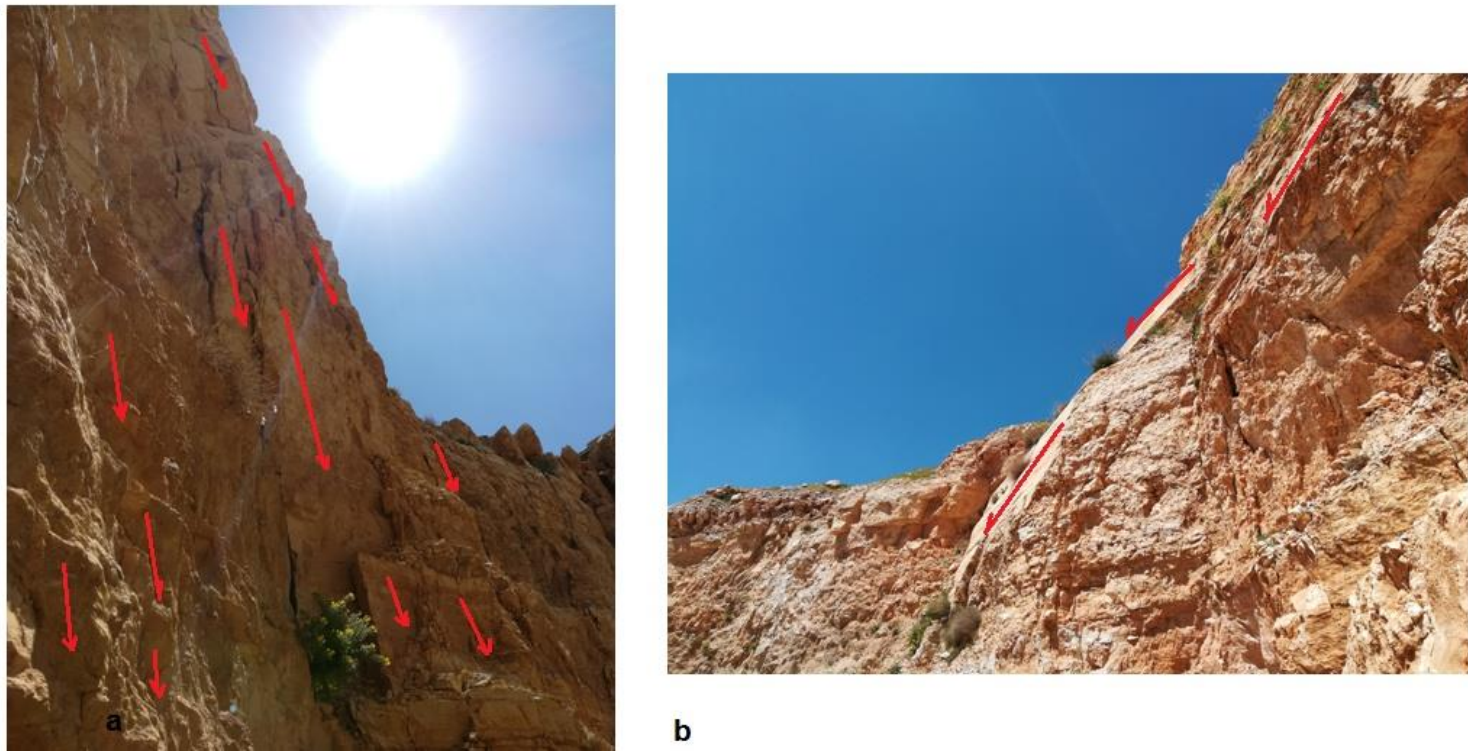

b

Fig.15. a) Slab planar sliding, b) planar sliding in the direction of red arrows

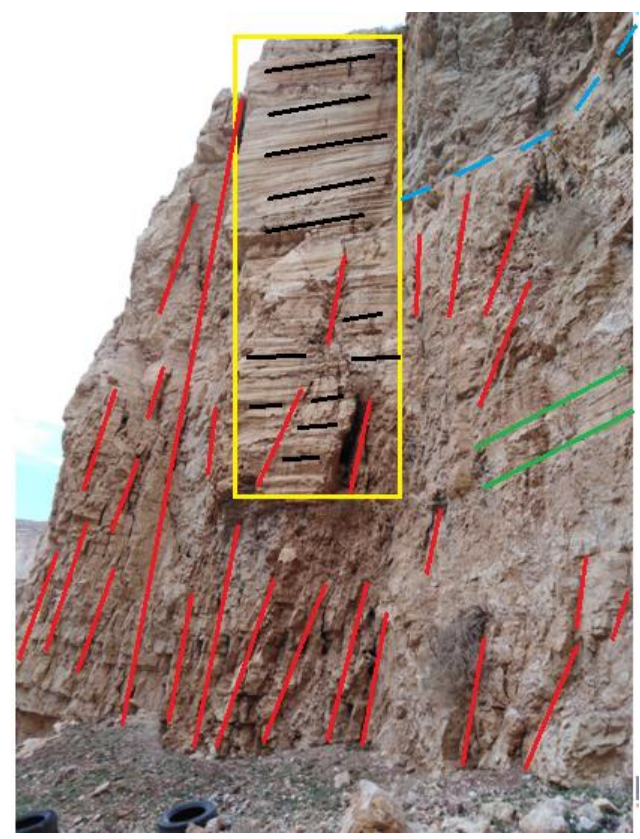

Fig.16. Highly deformed slope face by faulting inferred from horizontal slickensides (black dashes, yellow rectangle), vertical joints (red), listric fault (blue), the green lines indicates bedding attitude

\subsection{Station 3}

This station is located in the Huson quarry road, its coordination is $35^{\circ} 51^{\prime} 28^{\prime \prime} \mathrm{E}$ and $32^{\circ} 26^{\prime} 16^{\prime \prime} \mathrm{N}$ (Fig.3). It is an abandoned quarry beside active quarries, the fractures and the tracks of explosions still appear masses. 322 fractures were measured and represented as rose and stereonet diagrams (Fig. 17). The main trend of the discontinuities is striking NNE-SSW and minor trends in N-S and ENE-WSW (Fig. 17a). Results show that masses along three sets of discontinuities are probably unstable with respect to a slope face along the quarry toward WNW (Fig. 17b). These discontinuities are J1, J2 and J3 with attitudes of $280 / 80,110 / 80$ and $355 / 85$, respectively. The slope face is sub parallel to the main trend of the discontinuities (Fig. 17b), that allows to plane sliding along J1 toward WNW, toppling along J2 
toward WNW and wedge sliding along the intersection line of J1 \& J3 toward NW (Fig. 18b) (Figs. 1820).

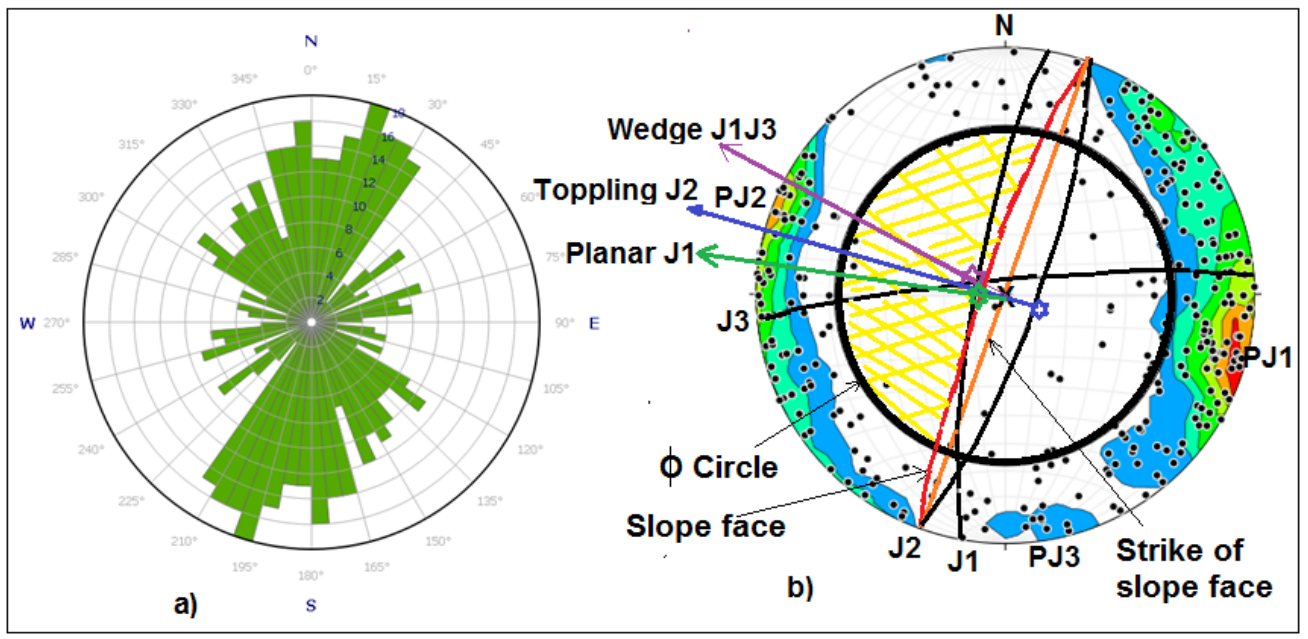

Fig. 17. Stability estimate of the rock mass in station3; (a) Strike orientation of 322 fracture measurements, (b) Poles of the discontinuities, contour plot of main concentrations of poles, and great circles of discontinuities normal to poles $\mathrm{J} 1, \mathrm{~J} 2$ and $\mathrm{J} 3$

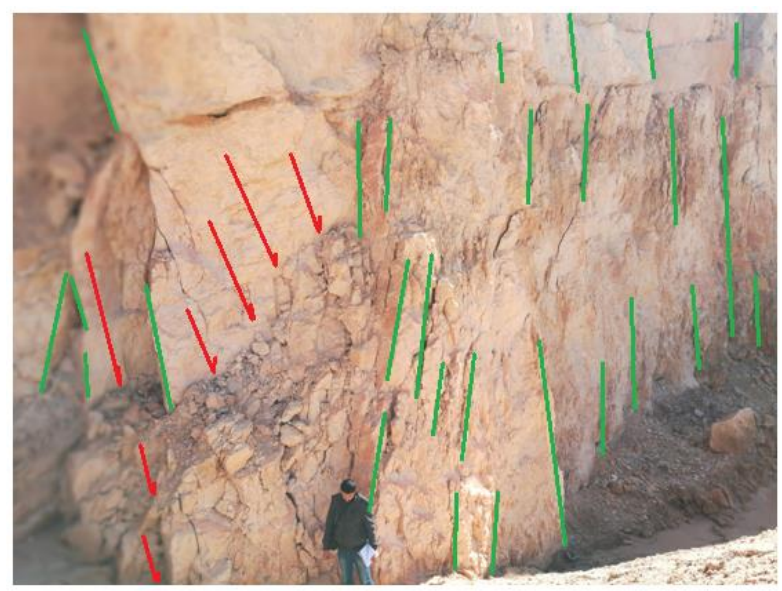

Fig. 18. Slab planar sliding (red arrows), vertical fractures (green)

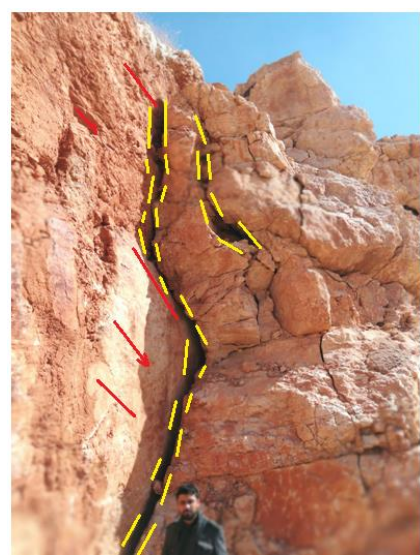

Fig.19. Tension cracks (yellow) along discontinuity plane (red) 

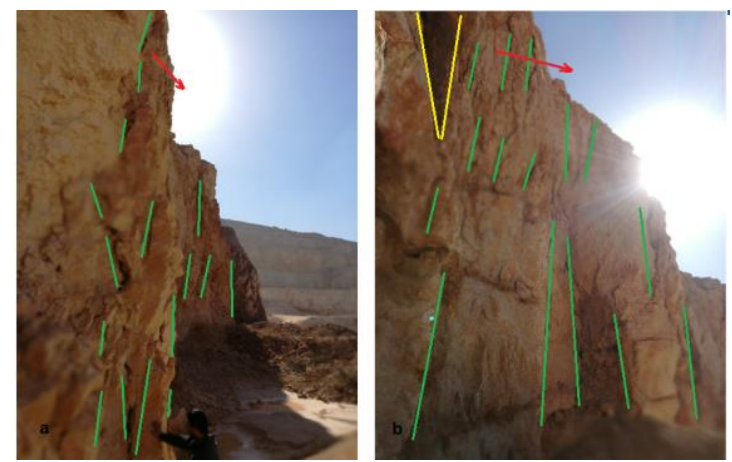

Fig. 20. Tension crack (yellow) and vertical fractures (green), and probability of toppling (red arrows)

\subsection{Station 4}

This station is an abandoned quarry in the east of the Huson- Shatana quarries road, it is located at $\left(35^{\circ} 51^{\prime} 04^{\prime \prime} \mathrm{E}\right.$ and $\left.32^{\circ} 26^{\prime} 09^{\prime \prime} \mathrm{N}\right)$ (Fig. 3). 358 fracture planes were measured and represented as rose and stereo plot diagrams (Fig. 21). Results show that NE-SW major trend, E-W and N-S minor trends (Fig. 21a). Results show that three sets of discontinuities are probably unstable with respect to a slope face along the quarry toward NW (Fig. 21b). These discontinuities are J1, J2 and J3 with attitudes of 160/85, 005/70and 260/80, respectively. The slope face is sub parallel to the main trend of the discontinuities that represents J1 (Fig. 21b), which shows toppling along J1 toward NNW, planar sliding along J2 toward N, and wedge sliding along the intersection line of J2 \& J3 toward NNW (Fig. 21b) and (Figs 22-24).This station shows water seepage (Fig. 22), which may affect the rock strength.

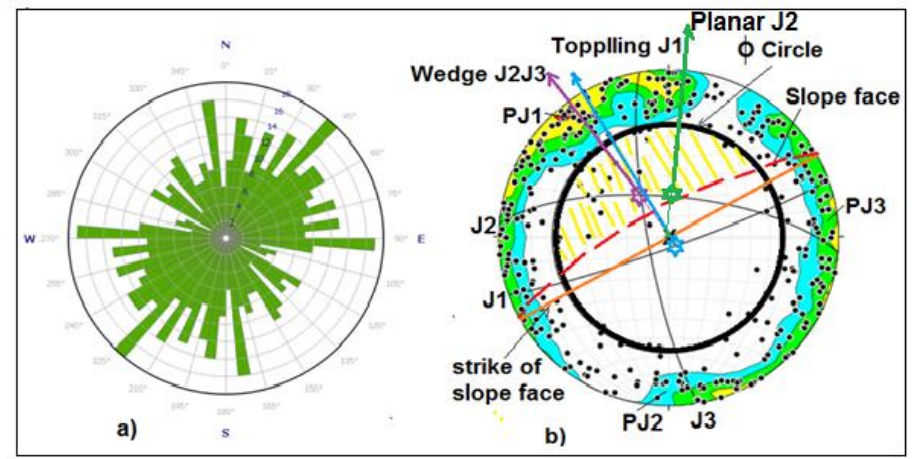

Fig. 21. Stability estimate of the rock mass in station-4; (a) Strike of 358 fracture measurements, (b) Pole plot of the discontinuities, contour plot of main concentrations of poles, and great circles of discontinuities normal to poles $\mathrm{J} 1, \mathrm{~J} 2$ and $\mathrm{J} 3$
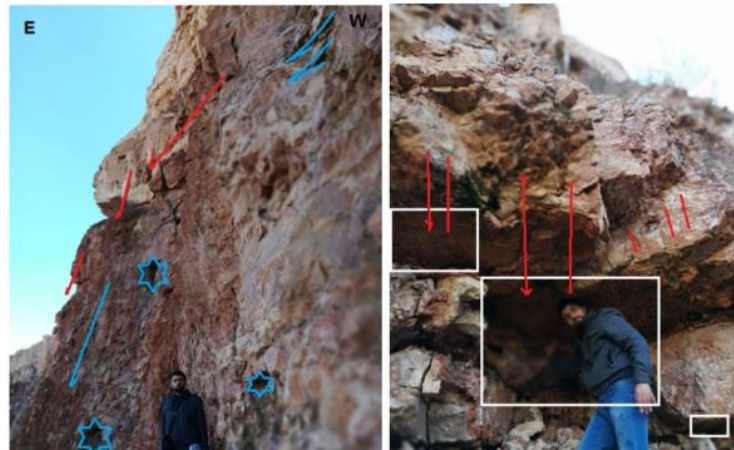

Fig. 22. Protruding blocks probable to fall (red), water seepage (blue arrows) and springs (blue stars) 


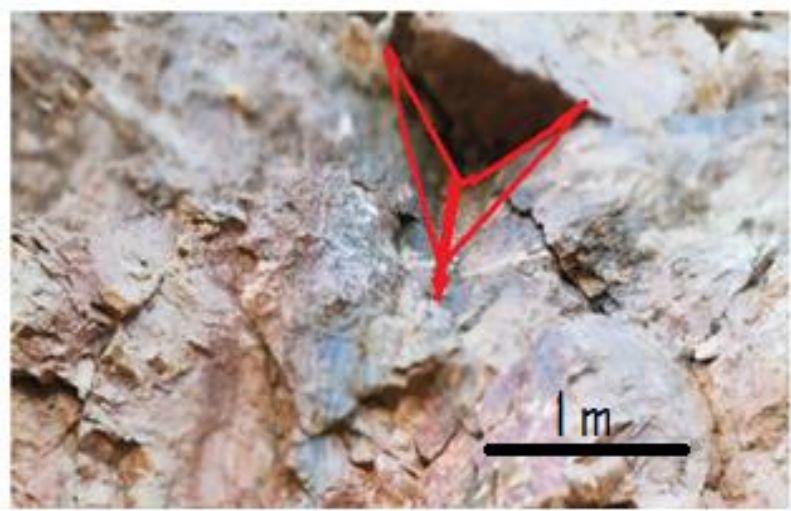

Fig. 23. Wedge sliding

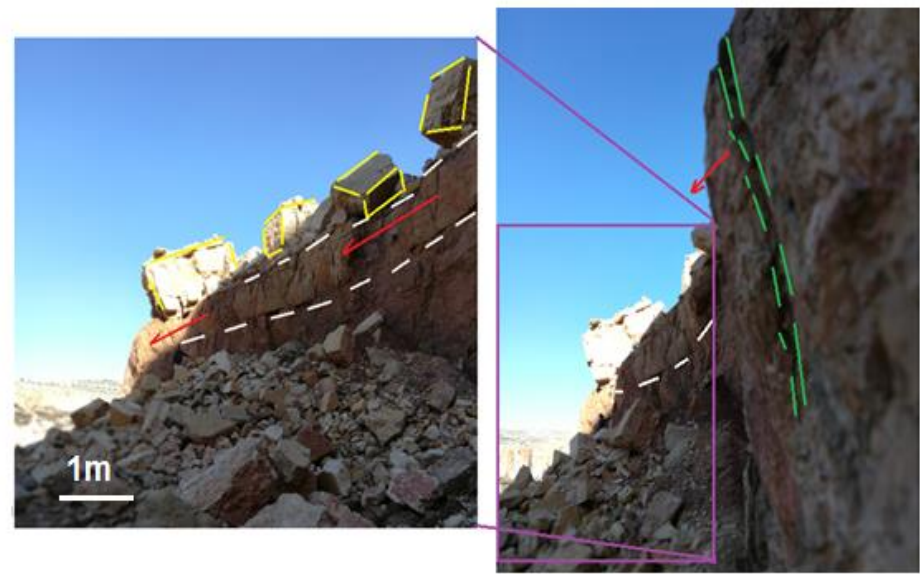

Fig. 24. Left) Planar sliding along bedding planes (white dashes), and Right) probability of toppling along tension crack (green)

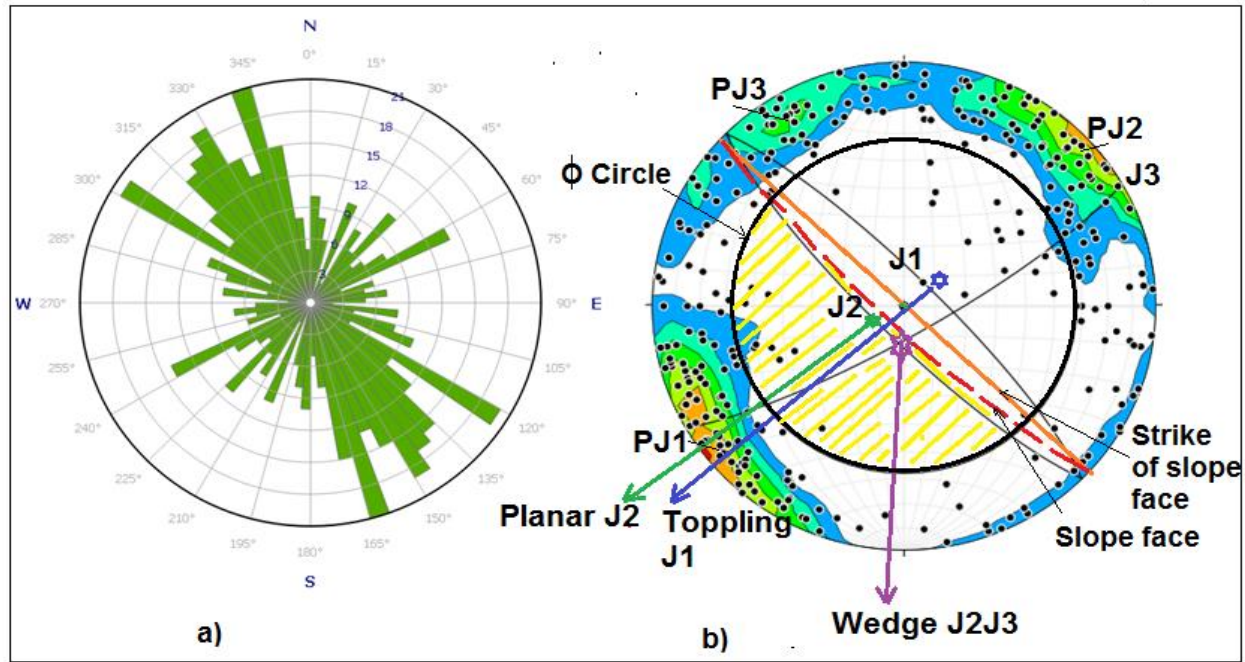

Fig. 25. Stability estimate of the rock mass in station-5; (a) Strike of 327 fracture measurements, (b) Pole plot of the discontinuities, contour plot of main concentrations of poles, and great circles of discontinuities normal to poles $\mathrm{J} 1, \mathrm{~J} 2$ and $\mathrm{J} 3$ 


\subsection{Station 5}

This abandoned quarry located in the west of the Huson-Shatana road, its coordination is $35^{\circ} 50^{\prime}$ $48^{\prime \prime} \mathrm{E}$ and $32^{\circ} 26^{\prime} 06^{\prime \prime} \mathrm{N}$ (Fig. 3). In this station 327 fractures were measured in this quarry. The rose diagram showed that NNW-SSE is the major trend and NW-SE and ENE-WSW are the minor trends (Fig. 25a). Results show that three sets of discontinuities are probably unstable with respect to a slope face dipping toward SW (Fig. 25b). These discontinuities are J1, J2 and J3 with attitudes of 045/80, $225 / 80$ and $150 / 80$, respectively. The slope face is sub parallel to the main trend of the discontinuities that represent $\mathrm{J} 1 \& \mathrm{~J} 2$. This indicates toppling along $\mathrm{J} 1$ and planar sliding along $\mathrm{J} 2$ toward SW (Fig. $25 \mathrm{~b}$ ). In addition to a wedge sliding along the intersection line of $\mathrm{J} 2 \& \mathrm{~J} 3$ towards $\mathrm{S}$ (Fig. 25b) and (Figs.

26-29).

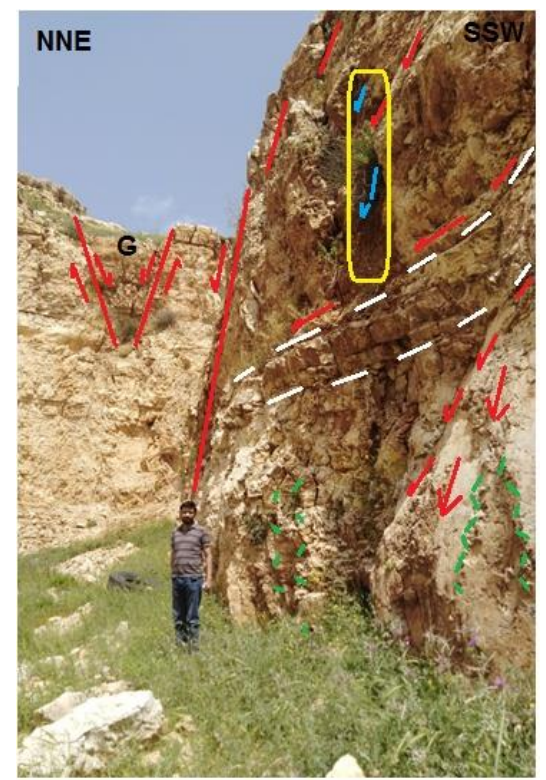

Fig. 26. Planar sliding along controlled structures; bedding planes (white dashes) and faults (red), stylolites (green seams), small graben $(G)$ in the sliding block along subvertical fault, tension fractures

(yellow) allow seepage of water (blue arrows), and rock falls

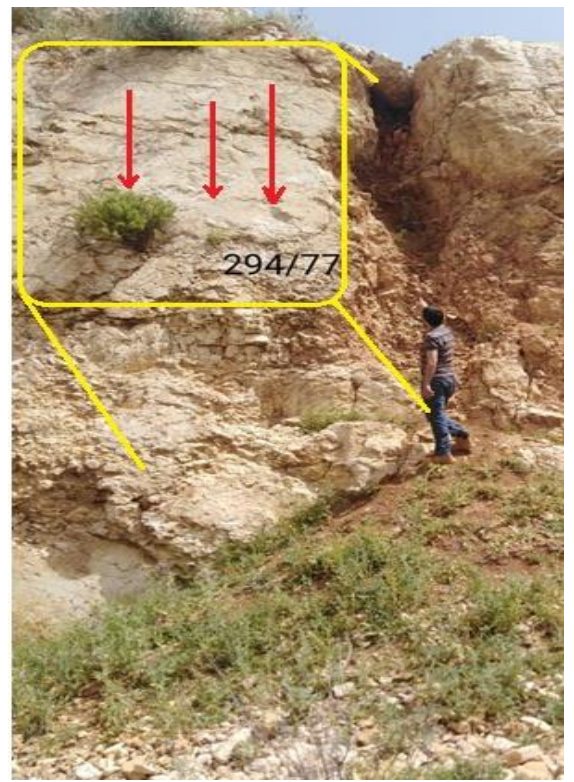

Fig. 27. Plane sliding along fault plane (red arrows) 


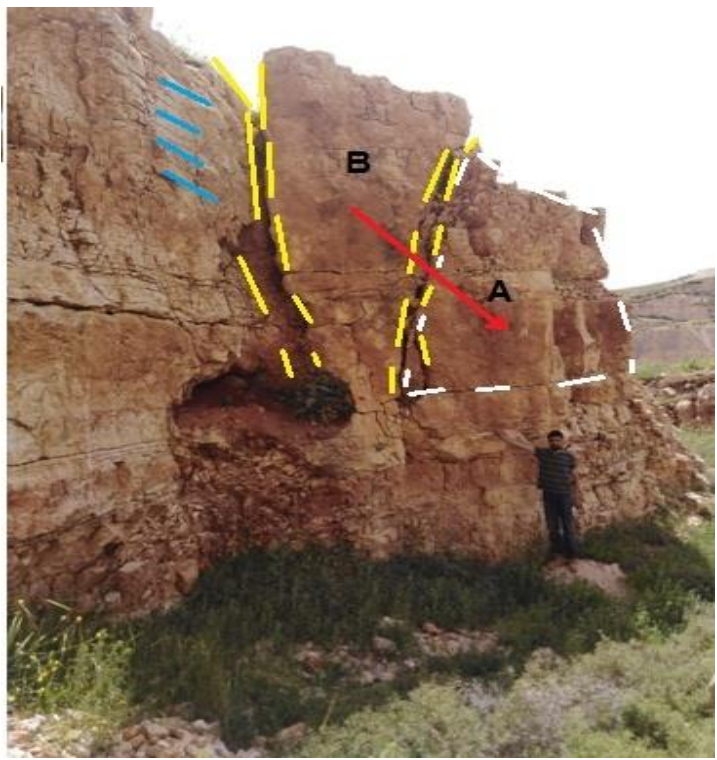

Fig. 28. Vertical to subvertical tension cracks along which block B probable to topple if block A (white dashes) is removed, oblique slickenlines (blue)

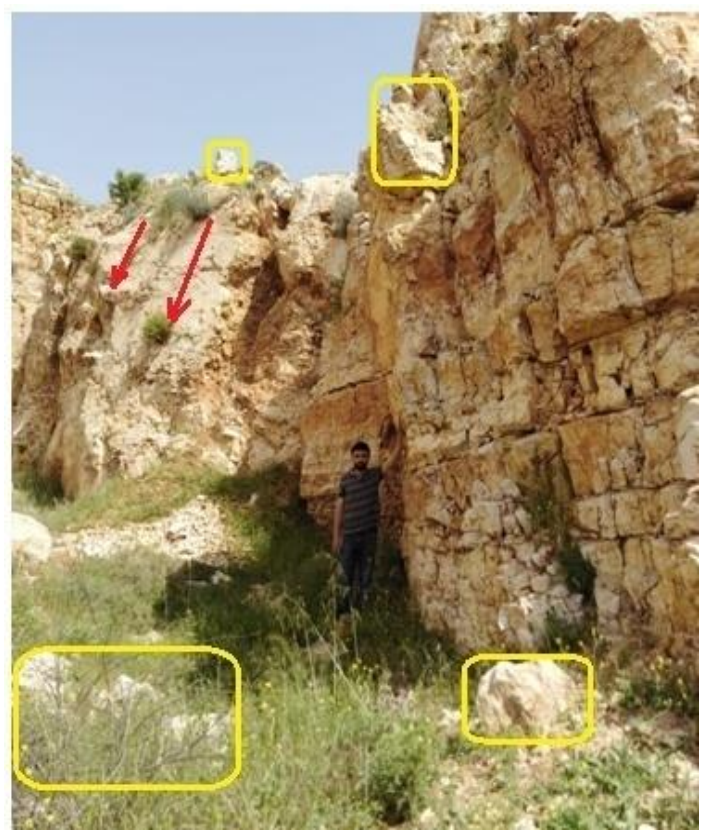

Fig. 29. Planar sliding along fault plane (red arrows), and rock falls (yellow)

\subsection{Station 6}

This station is located at the northwestern most part of the study area along the road of Habaka village, it is located at ( $35^{\circ} 50^{\prime} 04^{\prime \prime} \mathrm{E}$ and $32^{\circ} 27^{\prime} 58^{\prime \prime} \mathrm{N}$ ) (Fig. 3). 180 fractures were measured in the abandoned quarry surrounded by active quarries. Rose diagram plotted and shows the major trend is N-S to NNW-SSE and the minor is NW-SE (Fig. 30 a). Results show that three sets of discontinuities are probably unstable with respect to a slope face along the quarry toward W (Fig. 30b). These discontinuities are $\mathrm{J} 1, \mathrm{~J} 2$, and $\mathrm{J} 3$ with attitudes of $090 / 80,260 / 80$, and $170 / 85$, respectively. The slope face is sub parallel to the main and minor trends of the discontinuities that represent $\mathbf{J} 1, \mathrm{~J} 2 \& \mathrm{~J} 3$. This indicates toppling along $\mathrm{J} 1$ and planar sliding along $\mathrm{J} 2$ toward $\mathrm{W}$ (Fig. 30b). In addition to wedge sliding along the intersection line of J2 \& J3 planes toward SSW (Fig. 30b) and (Figs. 31- 33). 


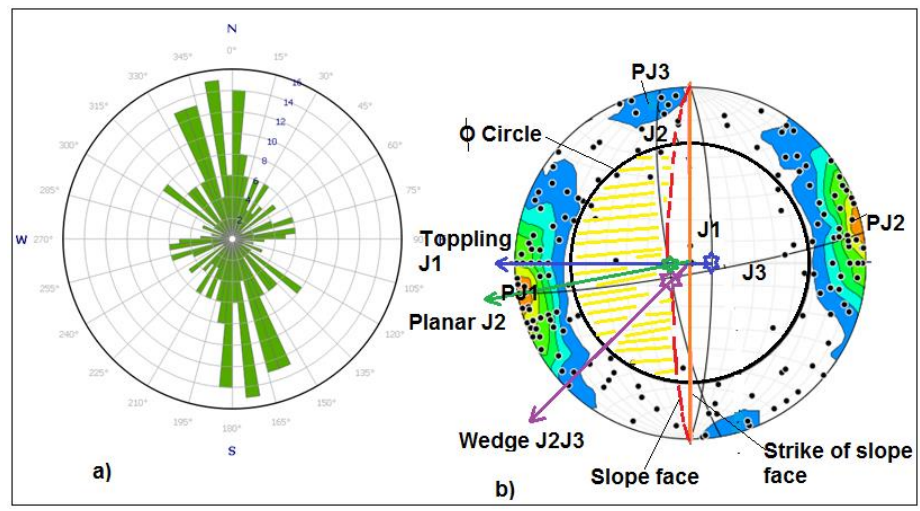

Fig.30. Stability estimate of the rock mass in station-6; (a) Strike of 180 fracture measurements, (b) Pole plot of the discontinuities and contour of main concentrations of poles, and great circles of discontinuities normal to poles $\mathrm{J} 1, \mathrm{~J} 2$ and $\mathrm{J} 3$
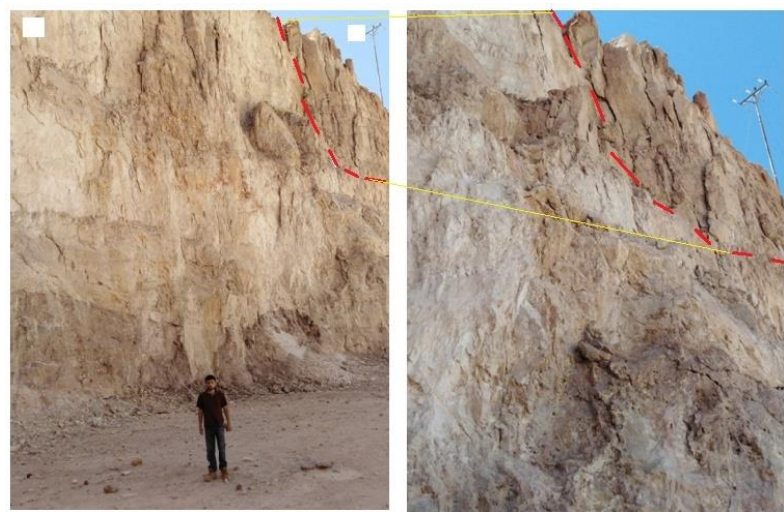

Fig.31. Slope face with highly vertical fractures make columns of rock with probability of planar sliding and rock falls

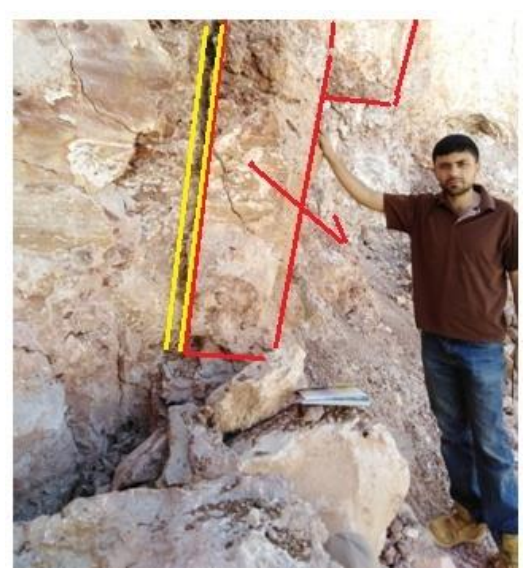

Fig.32. Large columns of rock probable to topple (red) and tension crack (yellow)

All the investigated quarries of the study area belong to the Wadi As Sir Formation. Five abandoned quarries are located at Al Huson- Shatana quarries road, whereas the sixth quarry is located at the northwestern most part of the study area, near Habaka village (Figs. $3 \& 34$ and table 2). The attitude of the discontinuities in the quarries were measured (dip direction/ dip) using CLAR compass. The data were presented as rose diagrams and analyzed using stereographic projection technique. 


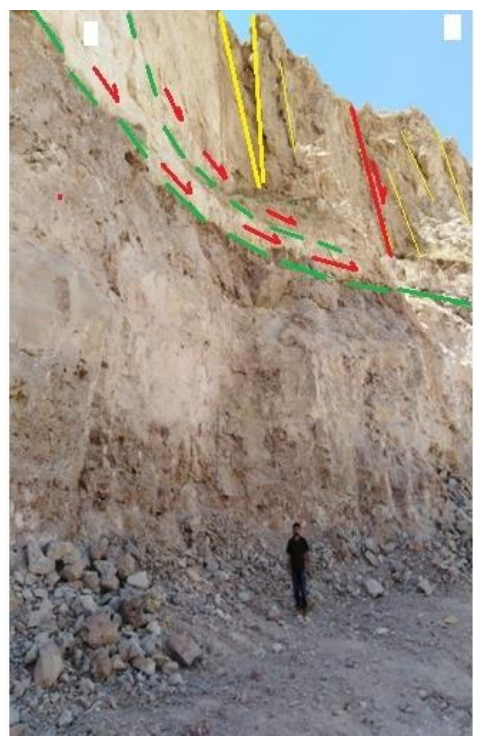

Fig. 33. Circular failure (green) and sliding along tension cracks (yellow) in direction of red arrows

Moreover, the coordinates of the stations and number of measurements and mode of failure that found out after kinematic analysis are summarized in the table 2. Results show that all the analyzed quarries have toppling, planer and wedge failures in addition to rock falls (Table 2). It is observed that, the most danger state of failure is likely to occur when the strike of the main trend of the discontinuities is parallel to sub parallel (20 degrees) to the strike of the slope face as in most stations of the study area (Fig. 34). In this case, toppling and plane sliding is dominated in most stations of the study area. It is also observed that the wedge sliding along the planes of faults and joints (discontinuities) is dominant.

Table 2. Results of kinematic analysis of the investigated stations

\begin{tabular}{|c|c|c|c|c|c|c|c|}
\hline Station & & Coordinates & $\begin{array}{l}\text { Number of } \\
\text { Measurements }\end{array}$ & $\begin{array}{l}\text { Major } \\
\text { trend }\end{array}$ & \multicolumn{2}{|c|}{$\begin{array}{l}\text { Joint sets } \\
\text { (Dip direction/ } \\
\text { Dip) }\end{array}$} & Mode of Failure \\
\hline \multirow{4}{*}{ Station 1} & $\mathrm{~S} 1$ & \multirow{4}{*}{$\begin{array}{l}\text { N } 102732 \\
\text { E } 145335\end{array}$} & \multirow{4}{*}{211} & \multirow{4}{*}{$\begin{array}{l}\text { WNW- } \\
\text { ESE }\end{array}$} & $\begin{array}{l}\mathrm{J} 2(020 / 60) \\
\mathrm{J} 4(250 / 70)\end{array}$ & $\begin{array}{l}\mathrm{J} 5(315 / 80) \\
\mathrm{J} 6(060 / 75)\end{array}$ & Wedge \& planar \\
\hline & S2 & & & & $\begin{array}{l}\mathrm{J} 1(190 / 55) \\
\mathrm{J} 2(020 / 60)\end{array}$ & $\begin{array}{l}\mathrm{J} 4(250 / 70) \\
\mathrm{J} 3(315 / 80)\end{array}$ & $\begin{array}{r}\text { Wedge, planar \& } \\
\text { toppling }\end{array}$ \\
\hline & S3 & & & & $\begin{array}{l}\mathrm{J} 1(190 / 55) \\
\mathrm{J} 3(090 / 80)\end{array}$ & $\begin{array}{l}\mathrm{J} 5(315 / 80) \\
\mathrm{J} 6(060 / 75)\end{array}$ & $\begin{array}{l}\text { Wedge, } \\
\text { Planar \& }\end{array}$ \\
\hline & S4 & & & & $\begin{array}{l}\mathrm{J} 1(190 / 55) \\
\mathrm{J} 2(020 / 60)\end{array}$ & $\begin{array}{l}\mathrm{J} 5(315 / 80) \\
\mathrm{J} 6(060 / 75)\end{array}$ & $\begin{array}{r}\text { Wedge, Planar \& } \\
\text { toppling }\end{array}$ \\
\hline \multirow{4}{*}{ Station2 } & S1 & \multirow{4}{*}{$\begin{array}{l}\text { N } 582632 \\
\text { E } 225235\end{array}$} & \multirow{4}{*}{422} & \multicolumn{3}{|c|}{$\begin{array}{c}\mathrm{J} 1(170 / 80) \quad \mathrm{J} 5(280 / 85) \\
\mathrm{J} 2(210 / 85)\end{array}$} & $\begin{array}{r}\text { Wedge \& } \\
\text { Planar }\end{array}$ \\
\hline & S2 & & & \multirow{3}{*}{$\begin{array}{l}\text { ENE- } \\
\text { WSW }\end{array}$} & $\begin{array}{r}\mathrm{J} 1(170 / 80) \\
\mathrm{J} 3(0\end{array}$ & $\begin{array}{l}\mathrm{J} 4(095 / 80) \\
0 / 85)\end{array}$ & $\begin{array}{r}\text { Wedge \& } \\
\text { toppling }\end{array}$ \\
\hline & S3 & & & & $\mathrm{J} 2(210 / 85)$ & $\mathrm{J} 3(030 / 85)$ & $\begin{array}{l}\text { planar \& } \\
\text { toppling }\end{array}$ \\
\hline & $\mathrm{S} 4$ & & & & $\mathrm{~J} 4(095 / 80)$ & $\mathrm{J} 5(280 / 85)$ & $\begin{array}{l}\text { planar \& } \\
\text { toppling }\end{array}$ \\
\hline Station 3 & & $\begin{array}{l}322616 \mathrm{~N} \\
355128 \mathrm{E}\end{array}$ & 322 & NNE-SSW & \multicolumn{2}{|c|}{$\begin{array}{l}\mathrm{J} 1(280 / 80) \\
\mathrm{J} 2(110 / 80) \\
\mathrm{J} 3(355 / 85)\end{array}$} & $\begin{array}{r}\text { Toppling, planar \& } \\
\text { wedge failure }\end{array}$ \\
\hline Station 4 & & $\begin{array}{l}322609 \mathrm{~N} \\
355104 \mathrm{E}\end{array}$ & 358 & NE-SW & \multicolumn{2}{|c|}{$\begin{array}{l}\mathrm{J} 1(160 / 85) \\
\mathrm{J} 2(005 / 70) \\
\mathrm{J} 3(260 / 80)\end{array}$} & $\begin{array}{r}\text { Toppling, planar \& } \\
\text { wedge failure }\end{array}$ \\
\hline Station 5 & & $\begin{array}{l}322606 \mathrm{~N} \\
355048 \mathrm{E}\end{array}$ & 327 & NNW-SSE & \multicolumn{2}{|c|}{$\begin{array}{l}\mathrm{J} 1(045 / 80) \\
\mathrm{J} 2(225 / 80) \\
\mathrm{J} 3(150 / 80)\end{array}$} & $\begin{array}{r}\text { Toppling, planar \& } \\
\text { wedge failure }\end{array}$ \\
\hline Station 6 & & $\begin{array}{l}322805 \mathrm{~N} \\
354955 \mathrm{E}\end{array}$ & 180 & $\begin{array}{l}\text { N-S to } \\
\text { NNW-SSE }\end{array}$ & \multicolumn{2}{|c|}{$\begin{array}{l}\mathrm{J} 1(090 / 80) \\
\mathrm{J} 2(260 / 80) \\
\mathrm{J} 3(170 / 85)\end{array}$} & $\begin{array}{r}\text { Toppling, planar \& } \\
\text { wedge failure }\end{array}$ \\
\hline
\end{tabular}




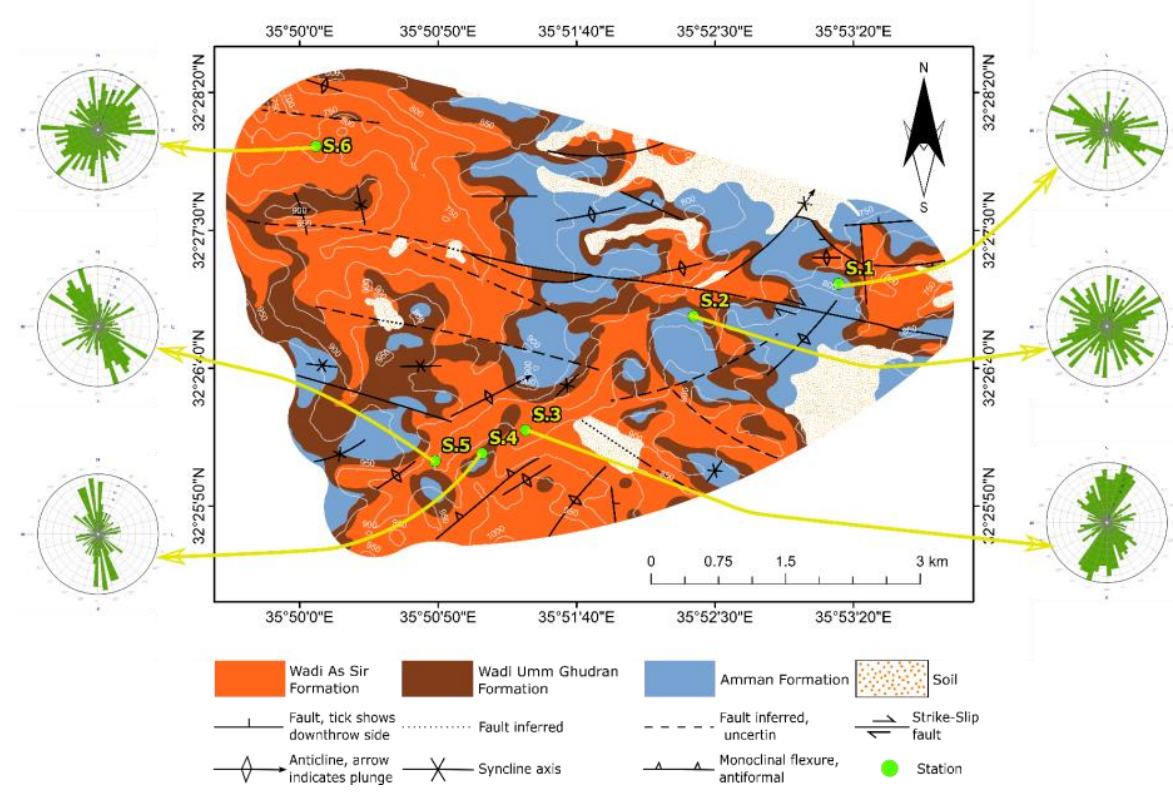

Fig. 34. Geological map showing the stations and rose diagrams represent strikes of discontinuities in each station

Fig. 34 shows more than one direction of strike of the fractures through the stations of the study area. This variation may be due to the major structures e.g., faults and folds in the study area and to local block rotation along them. In station1, six joint sets were identified with attitudes of: J1(190/55), J2 (020/60), J3 (090/80), J4 (250/70), J5 (315/80), J6 (060/75). These sets were analyzed with the related slope face and show the following: Along the slope face (S1), dipping toward NNE and parallel to the main trend of the discontinuities (Fig. 5 A ), are two wedges sliding; the first is toward NNE along the intersection line of $\mathrm{J} 5 \& \mathrm{~J} 6$ and the second is toward NW along $\mathrm{J} 2 \& \mathrm{~J} 4$, in addition to plane sliding along J2 toward NNE. The slope face (S2) dipping toward W (Fig. 5B) shows toppling along J3 toward W, planar sliding along J4 toward WSW, in addition to two wedges sliding; the first is toward SW along the intersection line of $\mathrm{J} 1 \& \mathrm{~J} 5$, and the second toward $\mathrm{NW}$ along the intersection line of $\mathrm{J} 2 \mathrm{~J} 4$. The slope face (S3) dipping toward E (Fig. 5 C) indicates toppling along J4 toward ENE, planar sliding toward E along J3, and two wedges sliding along J1J6 toward SE and along J3J5 toward NNE. The slope face (S4) dipping toward S (Fig. 5D) indicates plane sliding along J1 toward SSW, toppling along J2 toward SW and two wedges sliding along the intersection line of J1 \& J5 toward WSW and along J1J6 toward SE (Table 2). In station 2, there are five sets of discontinuities with attitudes of J1(170/80), J2(210/85), J3(030/85), J4(095/80) J5(280/85). These sets were analyzed with the related slope face and show the following: the slope face (S1) dipping toward SSE that parallel to the main trend of the discontinuities (Fig. 11A) shows plane sliding along J1 toward SSE and wedge sliding along the intersection line of J2J5 toward SSE. The slope face (S2) dipping toward SSW (Fig. 11B) shows toppling along J3 and wedge sliding along the intersection line of J1J4 toward SSW. The slope face (S3) dipping toward NE (Fig. 11C) indicates toppling along $\mathrm{J} 2$ and planar sliding along $\mathrm{J} 3$ toward NNE. The slope face (S4) dipping toward WNW (Fig. 11D) indicates planar sliding along J4 toward W, and toppling along J5 toward W (Table 2).

Station 3 has three major sets of discontinuities, the slope face is sub parallel to the main trend of the discontinuities (Fig. 17), their attitudes as follows: J1(280/80), J2 (110/80), J3(355/85). It shows planar sliding along $\mathrm{J} 1$ toward WNW, toppling along $\mathrm{J} 2$ toward WNW and wedge sliding along the intersection line of $\mathrm{J} 1 \& \mathrm{~J} 3$ toward NW (Table 2). In station 4 three major sets were found with attitudes of, J1(160/85), J2(005/70) and J3 (260/80) (Fig. 21), which shows toppling along J1 toward NNW, planar sliding along $\mathrm{J} 2$ toward $\mathrm{N}$, and wedge sliding along the intersection line of $\mathrm{J} 2$ \& $\mathrm{J} 3$ toward $\mathrm{NNW}$ 
(Table 2). Station five has three major sets of discontinuities, J1(045/80), J2 (225/80) and J3 (150/80). Kinematic analysis indicates toppling along J1 and planar sliding along J2 toward SW (Fig. 25). In addition to wedge sliding along the intersection line of $\mathrm{J} 2 \& \mathrm{~J} 3$ planes toward $\mathrm{S}$ (Table 1). At last, in station six has identified three joint sets: J1(090/80), J2 (260/80), J3 (170/85). This indicates toppling along $\mathrm{J} 1$ and planar sliding along $\mathrm{J} 2$ toward $\mathrm{W}$ (Fig. 30). In addition to wedge sliding along the intersection line of J2 \& J3 planes toward SSW (Table 2). In conclusion, the results of kinematic analysis in the study area show that, toppling, planar and wedge failures are likely to occur in all stations mainly along structural discontinuities e.g., faults and joints. This indicates the role of structures in the rock landslides, particularly those related with planar, wedge and toppling failures.

\section{Conclusions}

The Kinematic analysis provides a very useful method to determine the possible mechanisms of failure in rock masses. This analysis resulted in the determination of the directions of Wedge, planar and toppling failures that were expected in the stations of the study area. Rock falling was also observed in all stations of the study area. The instability of the quarry walls in the study area comes from the structural discontinuities (e.g., faults and joints), and from the artificial over steepening of slopes during excavations in the quarries.

\section{Recommendations}

- Carrying out other researches to the same area by using other methods and techniques e.g., limit equilibrium, numerical modeling, and empirical methods.

- Strict rules to the safety ways after the companies retreat from the sites, by using benches, fencing, burying ways and not let the sites without treatment of the falling a parting cliff.

- Control the water seepage in station four, because it decreases the rock strength and increasing the instability by increasing shear stresses.

\section{Acknowledgements}

The authors would like to express their gratitude to the anonymous reviewers for critically reviewing the manuscript and offering constructive comments. The authors are very grateful to the Editor in Chief Prof. Dr. Salih M. Awadh, the Secretary of Journal Mr. Samir R. Hijab. and the Technical Editors for their great efforts and valuable comments.

\section{References}

Abad, S. A. N. K., Mohamad, E. T., Hajihassani, M., Kalatehjari, R. and Namazi, E. 2011. Rock slope stability assessment by using kinematic analysis and slope mass rating at Bandar Seri Alam, Johor. National Geoscience Conference, 1-19.

Abed, A. M., 2000. Geology of Jordan, first edition. Jordanian Geologists Association. (In Arabic). Amman, Jordan.

Abdelhamid, G., 1995. The geology of Jarash Area. Map Sheet (3154-I), Report of Natural Resources Authority.

Al-khatib, N., Atallah, M., Diabat, A., 2010. Paleostress analysis of the Cretaceous rocks in northern Jordan. Jordan Journal of Earth and Environmental Sciences, 3, 25-36.

Al-Tawalbeh, M., Atallah, M., \& Al Tamimi, M. 2017. Structural evolution of the area north of Ajloun Dome, Jordan. Jordan Journal of Earth and Environmental Sciences, 8 (2), 55-60.

Barton, N., 1973. Review of a new shear-strength criterion for rock joints. Engineering Geology, 7(4), $287-332$.

Basahel, H., Mitri, H., 2017. Application of rock mass classification systems to rock slope stability assessment: A case study. Journal of Rock Mechanics and Geotechnical Engineering, 9(6), 993-1009.

Ben-Avraham, Z., Lazar, M., Schattner, U., \& Marco, S. 2005. The Dead sea fault and its effect on civilization. in Wenzel, F. (Ed.), Perspectives in Modern Seismology, 145-163. 
Bender, F., 1974. Geology of Jordan. Brontrager, Berline,196.

Diner, J., 2019. Failed rifting in Jordan and the development of the Dead Sea Transform. Journal of Geodynamics, 124, 104-118.

Jaeger, J., Cook, N., 1976. Fundamentals of Rock Mechanics, 2nd Ed. (Chapman and Hall, London).

Koca, M. Y., Kincal, C., 2004. Abandoned stone quarries in and around the Izmir city center and their geo environmental impacts, Turkey. Engineering Geology, 75(1), 49-67.

Masri, M. R., 1963. Report on the geology of Amman-Zarga area. Central Water Authority,Amman, Jordan.

Masson, F., Hamiel, Y., Agnon, A., Klinger, Y., Deprez, A., 2015. Variable behavior of the Dead Sea Fault along the southern Arava segment from GPS measurements. Comptes Rendus Geoscience, 347(4), 161-169.

Powell, J. H., 1989. Stratigraphy and Sedimentation of the Phanerozoic rocks in central and south Jordan. Part B: Kurnub, Ajlun and Balqa Groups, Bull. 11, NRA, Geol. Directorate, 130.

Samarawickrama, M. N. C., Perera, H. S. C., 2006. Evaluation of operations capability of Lanka mineral sand limited. In Proceedings of International Conference on Business Management, 3. 